\title{
CONTRIBUTION TO THE STUDY OF ROMAN ARCHITECTURE IN VIMINACIUM: CONSTRUCTION MATERIALS AND BUILDING TECHNIQUES*
}

\begin{abstract}
Owing to the facts that Viminacium has, for centuries, had its buildings destroyed and that small number of buildings have been investigated so far, there are only a very few visible traces of its architecture. Therefore, the study of construction materials and building techniques represents just a small contribution to the general study of its architecture.Locally produced brick and stone from the nearby quarry, bound with lime mortar, represented basic construction materials of Viminacium. Those, available materials, influenced the development of the applied building techniques.
\end{abstract}

Keywords: Viminacium, green schist, brick, limestone, lime mortar, "crvenka“, opus incertum mixtum, opus testaceum, "trpanac", pozzolanic feature.

\section{CONSTRUCTION MATERIALS OF VIMINACIUM BUILDINGS**}

One of the basic rules of ancient Roman architecture was the usage of local materials. (Radivojevic, Kurtović-Folić 2006: 693) This rule was also applied to the buildings of ancient Viminacium.

\section{Stone}

The basic stone type used by the Romans from Viminacium was green schist, locally called "zelenac" (the green stone), presumably deriving from the quarry in the nearby village of Ram, in which it is still being quarried. (Fig. 1) The village of Ram, actually Roman Lederata and the later mediaeval fortresses, is situated some $15 \mathrm{~km}$ from Viminacium. The fortress visible today is Turkish, dates from the 15th century and was also built of this stone. (Fig. 2) (Каниц 1989:538-539). Green schist is a stone often found in the quarries of eastern Serbia and is, therefore, often present in many of the historic buildings of this area. Roman metallurgic centre dated to the period from the end of the $3^{\text {rd }}$ to the end of the $4^{\text {th }}$ century, Kraku lu Jordan, today an archaeological site near Kučevo, possesses walls completely built out of the same stone quarried from the hill in which the centre is situated. (Bartel, Kondić 1979:133,135) Other stone types present in the walls of the Viminacium buildings

*The article derives from the project: Viminacium, Roman city and military camp - research of material and non material culture of inhabitants by using the modern technologies of remote detection, geophysics, GIS, digitalisation and $3 D$ visualisation (no 47018), funded by the Ministry of Education, Science and Technological Development of the Republic of Serbia.

**The author owes the gratitude to Ivana Delić - Nikolić, geologist from the Institute for testing materials in Belgrade, for the research of Viminacium mortars and valuable advices and conclusions on the topic. 


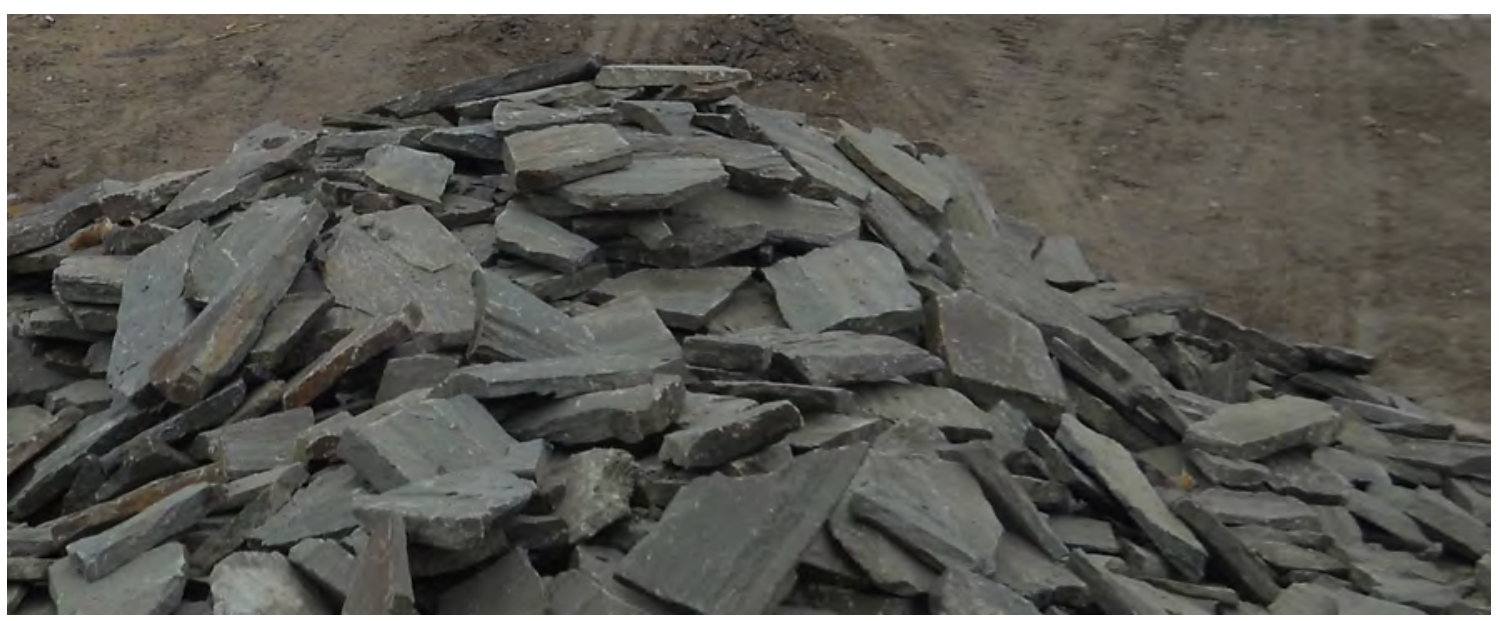

Fig. 1 Green schist from Ram quarry, Photo by the author.

excavated so far include limestone in the large blocks forming the walls of huge buildings, very rare deposits of tufa, as well as sandstone in large blocks, used for the final layer of roads. Sandstone was used for the entrance to the northern gate of the Viminacium fort, as well as at one of the amphitheatre entrances.

Since today there are a very few visible architectural remains at Viminacium, one can gain

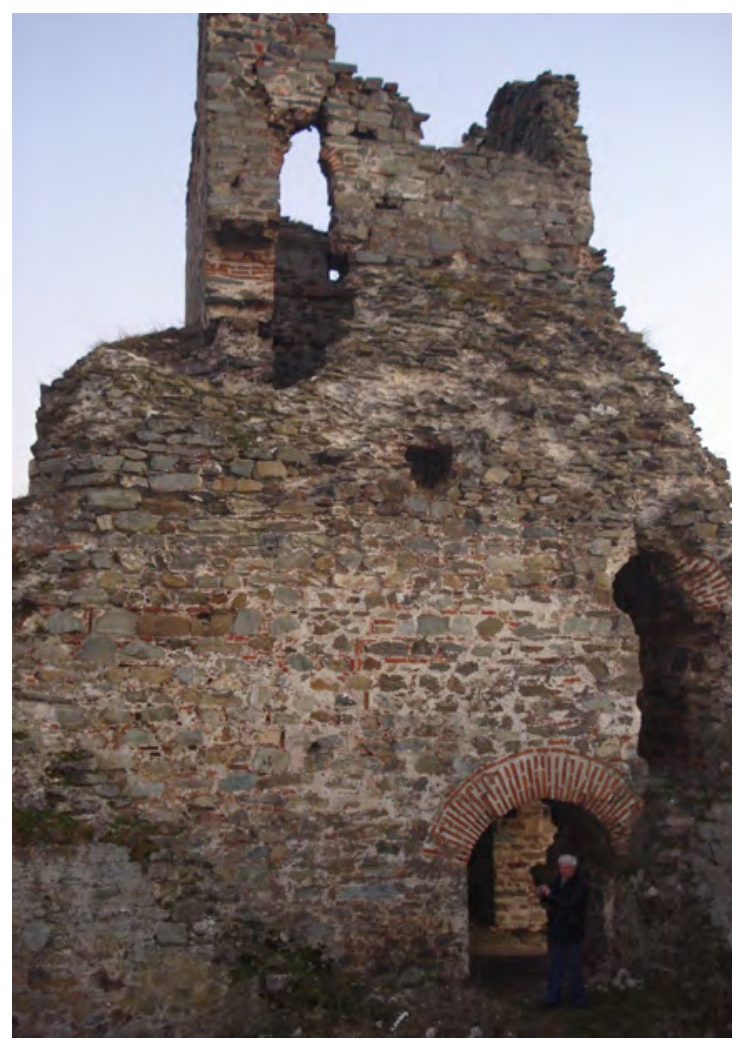

Fig. 2 Mediaeval Ram fortress. Photo by the author. data about the use of stone from reports about old archaeological research, and also from travel reports from the $19^{\text {th }}$ century.

In 1974, in one of the trenches which was later covered, a building was excavated, with large limestone blocks used for the staircase and for strengthening of the wall angles.(Zotovic 1974:48-49, Table XXV, Каниц 1987:177) The socle of the Early Byzantine building at the site "Svetinja" was built out of large stone blocks brought from the destroyed Roman buildings of Viminacium. (Popovic 1987:6-9) It is interesting to read parts of the book by the Austrian travel-writer Felix Kanitz, in which Viminacium is mentioned and how its remains were scattered over its surrounding area, among which there were column parts measuring $0.70 \mathrm{~m}$ in diameter and $2.85 \mathrm{~m}$ in length. (Каниц 1987:177)

Nevertheless, near Viminacium there are no sources of limestone or sandstone, or any other sort of stone suitable for cutting into regular rectangular blocks. (Васић 1907:67) Stone sarcophagi, both simple ones and those having stone plates, were brought from distant quarries“. (Валтровић 1884:124) The Romans used waterways to transport stone. In the case of Viminacium, these rivers were The Mlava and The Danube. Most likely, the quarries of limestone used for the Viminacium buildings would have been located along the Danube, upstream, from Kostolac, via Smederevo and Grocka, towards Belgrade. (Fig. 3a i 3b) This opinion is supported by the writings of Felix Kanitz about the quest for the ancient settlement Aureus Mons near Smederevo, towards the settlement of Seone. He writes that "the stones 


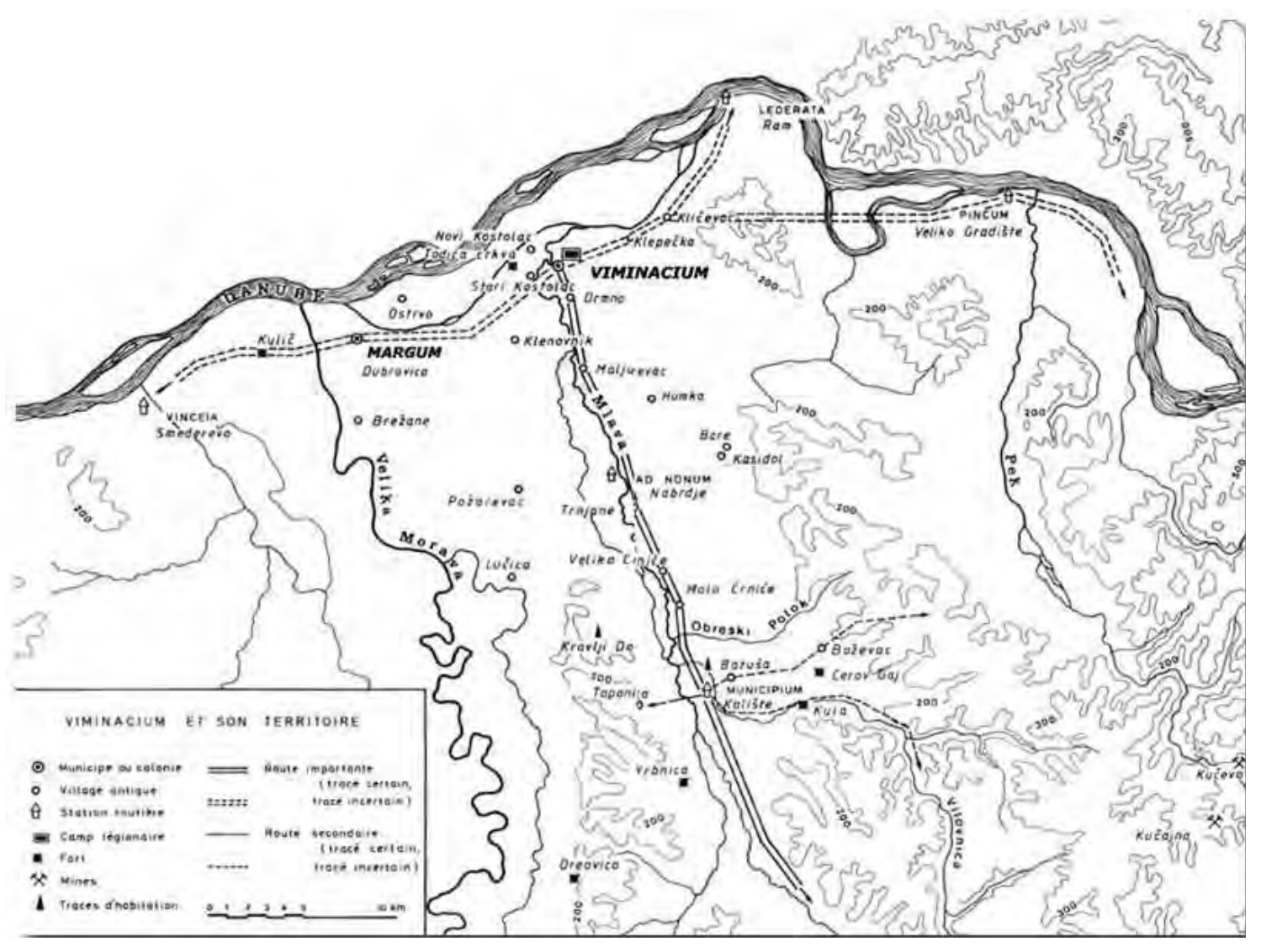

Fig. 3a Viminacium and Margum with Danube. Mirković, Miroslava. Inscriptions de la Mésie Supérieure, vol II, Viminacium et Margum. Beograd: Centre d’études épigraphiques et numismatiques, De la Faculté de philosophie de l’Université de Beograd, 1986

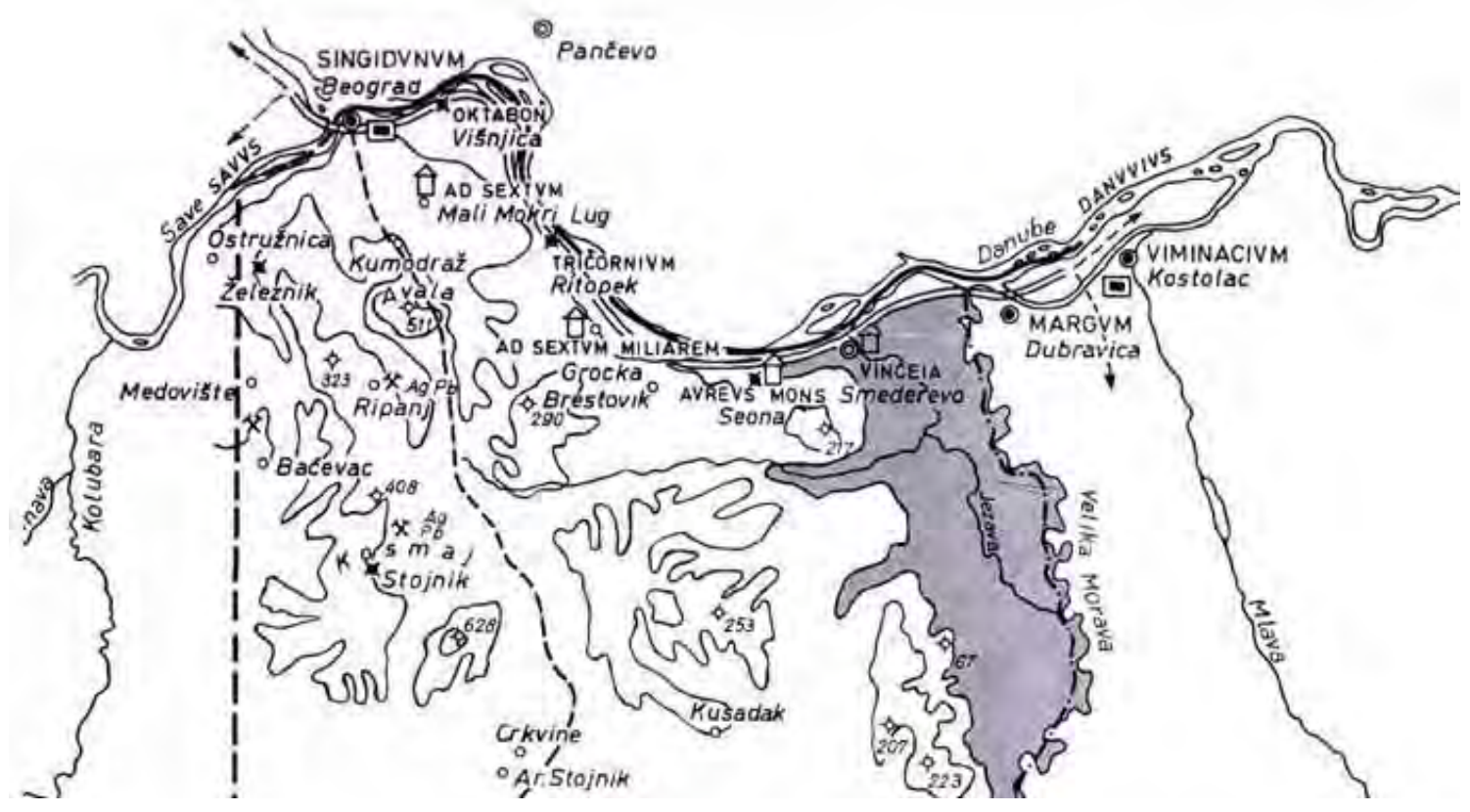

Fig. 3b Roman towns and forts along the Danube. Mirković, Miroslava i Dušanić, Slobodan. Inscriptions de la Mésie Supérieure, vol I, Singidunum et le nord-ouest de la province. Beograd: Centre d'études épigraphiques et numismatiques, De la Faculté de philosophie de l’Université de Beograd, 1976. 
for its walls, partly preserved, originate from Višnjica, lying to the northwest at a distance of some 25 km". (Каниц, 1987, 155), and in later writings it is mentioned as a place situated some 24 to 25 miles away from Viminacium. (Mirković 1968: 61) Kanitz also reports on the quest for the ancient settlement Vinceia, also close to Smederevo, near the settlement of Ćirilovac: “...we soon actually discovered foundations made of Ram mica shale and walls of bricks and Tertiar limestone from Višnjica”. (Каниц 1987:157) During archaeological research in 1964 in the modern Belgrade suburb of Višnjica, a Byzantine fort from the $6^{\text {th }}$ century Ad Octavum was discovered, with buildings "made of stone blocks from the nearby quarry". (Каталог непокретних добара на подручју Града Београда)

Here, modern quarries in the vicinity of Kučevo, Žagubica and Petrovac na Mlavi should

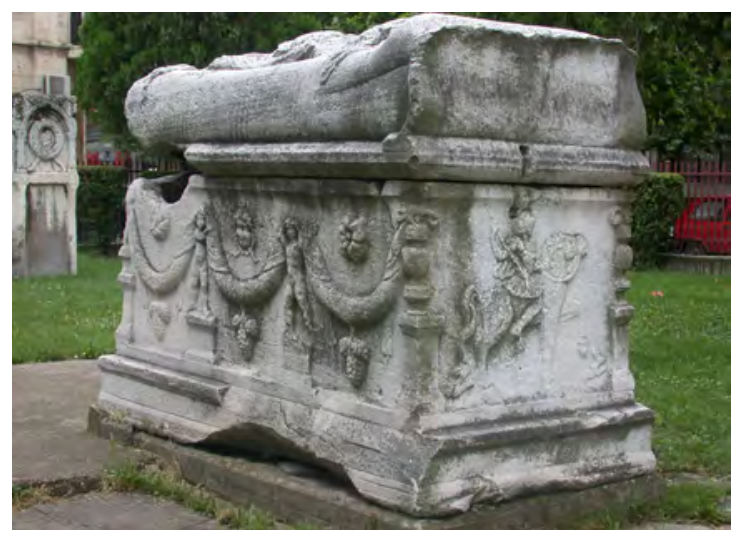

Fig. 4 "Proconesic sarcophagus with garlands". Photo by the author.

be mentioned, but also the well-known ones on Avala and Kosmaj, actually the ancient mining centres. As far as the mentioned tufa is concerned, there is a settlement in Homolje near Mlava bearing the same name as tufa in Serbian, ie. Siga, in which there is a quarry. Limestone used for the production of lime mortar made for the mentioned centre Kraku lu Jordan derives from a quarry some $20 \mathrm{kms}$ away from this site, to the west of Kučevo, down the Pek river. (Bartel, Kondić 1979:133,135)

It is important to mention recent research connecting the Roman quarry in the village of Dardagani near Zvornik in Bosnia with ancient Sirmium, which actually determines the origin of the limestone used to build this imperial town. According to this research, the limestone was brought to Sirmium along the river Sapna, and later along the Drina and the Sava.(Đurić, Davidović. Maver and Müller, 2006, 103-137) The limestone analyses showed that the stone originated from the quarry in Dardagani, but also from other quarries, in the Eastern Alps and the Mediterranean. (Đurić, Davidović. Maver and Müller 2006:103-137)

Since Viminacium was an important urban centre, it can be presumed that luxurious stones intended for building were often transported to it from distant quarries. An example of expensive and imported materials in the territory of Viminacium is also found in the "Proconesic sarcophagus with garlands" made of Proconesic marble and imported from the modern island of Marmara in Turkey, former Proconesu. (Fig. 4) Today it is kept at the lapidarium of the National Museum in Požarevac. (Томовић 1991:69-70).

In 1968, a Roman bath, built in the $3^{\text {rd }}$ century A.D. and used until the $4^{\text {th }}$ century, was discovered under Studentski trg in modern Belgrade (ancient Singidunum), for which the Tašmajdan limestone was presumably used. (Бојовић 1977:5-22) Since this stone could have been easily transported down the Danube to Viminacium, it is plausible that it could have been also used for constructing its buildings. It is interesting to note that in the baths of the nearby ancient Margum, the modern village of Dubravica near Pozarevac, large quantities of "quite regularly cut stone blocks" were used. (Цуњак 1995-1996:107) Therefore the question of its origin arises, actually its source which, because

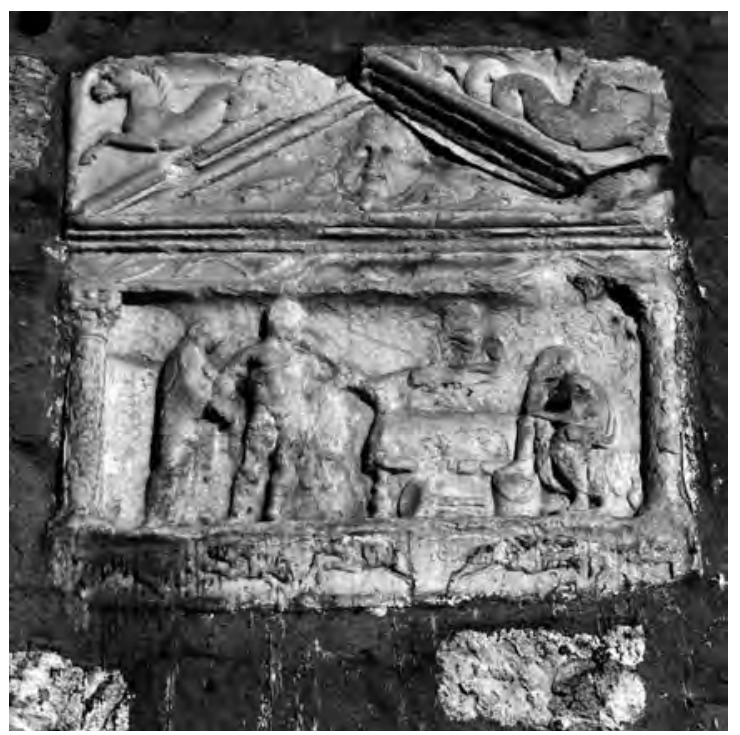

Fig. 5 Tombstone probably originated from Viminacium, built in Smederevo fortress wall. Цветковић 2009:37 


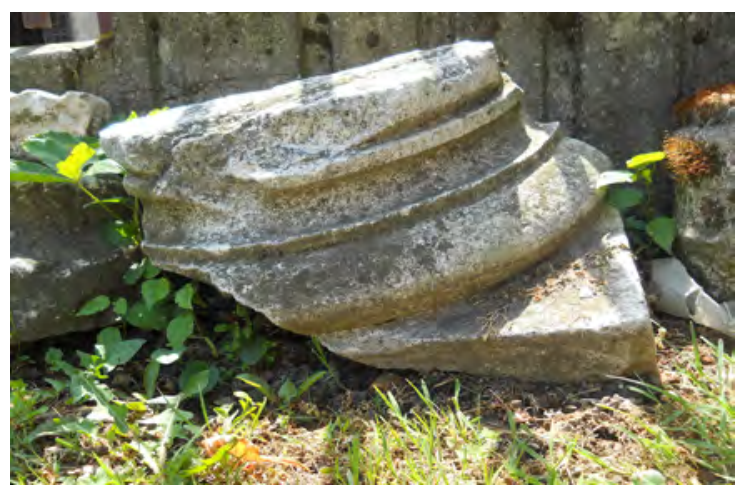

Fig. 6 Base of a column from Požarevac museum lapidarium. Photo by the author.

of the small distance between these two ancient towns, i.e. 10 miles (Fig. 3b), (Mirković 1968:50) must have also been accessible to the constructors of Viminacium.

Travel reports and notes made by travel-writers from the $19^{\text {th }}$ century mention the use of luxurious stones in the upper parts of some of the Viminacium buildings, such as porphyry pillars made out of single blocks, as well as sarcophagi of granite

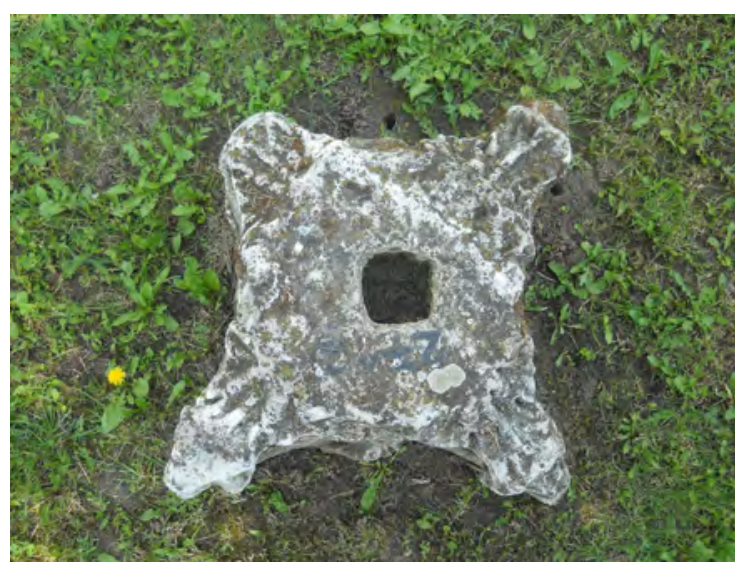

Kostolac, Kanitz discovered two stone reliefs built in its walls. Within the Smederevo fort walls, many gravestones originated from Viminacium were noted, reliefs and figural sculptures. (Каниц, 1987, 150-152, 165, 177-179, 181) (Fig. 5) It is interesting to mention the secondary usage of the building material for constructing the early Byzantine defense wall on the Viminacium site "Svetinja”, i.e. fragments of architectural plastic of Viminacium built into it. (Поповић, 2009, 2944) In the lapidarium of the National Museum in Požarevac, as well as in the Viminacium archaeological park, smaller stone fragments of pillars are exhibited, along with damaged bases and capitels and parts of architraves. (Fig. 6 - Fig.11)

\section{Brick}

The basic building material used by the Romans in the territory of modern Serbia was brick. (Radivojevic, Kurtović-Folić 2006:693) Since no stone suitable for building and cutting was available, the Viminacium builders were focused on

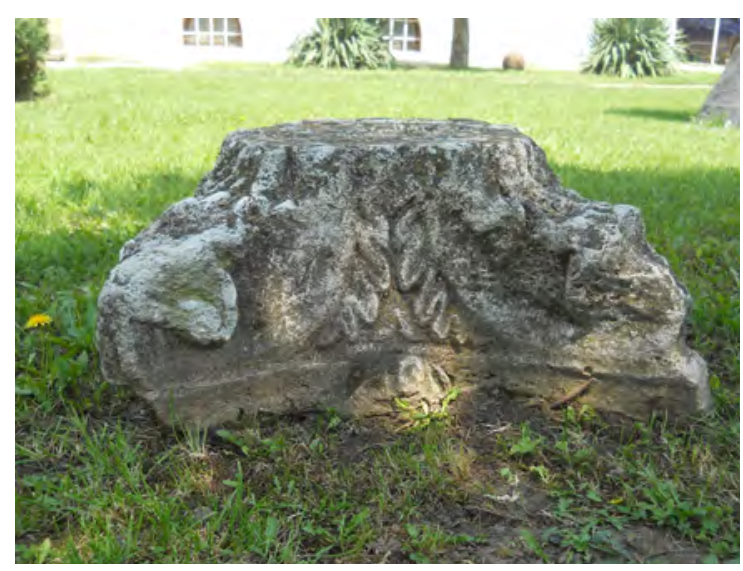

Fig. 7 Corinthian capital from Požarevac museum lapidarium. Photo by the author.

porphyry and marble. (Каниц 1987:180-181) In addition, excavation reports mention a pillar made of pink marble.(Поповић 1987:3)

Indications of stone material used in Viminacium can also be obtained through observations of the building material of the nearby area, since "Byzantine and Bulgarian fortresses, Serbian castles and churches" (Каниц 1987: 179), like the Smederevo fort, the Nimnik monastery and a large number of houses in the nearby villages and the town of Požarevac, were made out of bricks and stones from Viminacium (Цветковић 2009: 29, 35, 37, 38). In the priest’s house in Stari brick. (Васић 1907:69) All sediments under the site of Viminacium are rich in clay and loess with a high percentage of clayish components covers most of the area (Mašinski fakultet Univerziteta u Beogradu 2010:20-24) which helped the developing of brick "industry" in this Roman city. (Васић 1907:69) Until recently, on one of the sites in the wider Viminacium area, a "former earth mine... a long valley... where the Romans dug out clay for bricks" (Валтровић 1884:98-99) was visible, actually a deep and spacious depression for obtaining earth. (Васић 1907:68-69) It is the site "Kod Koraba”, which, after the archaeological research, 


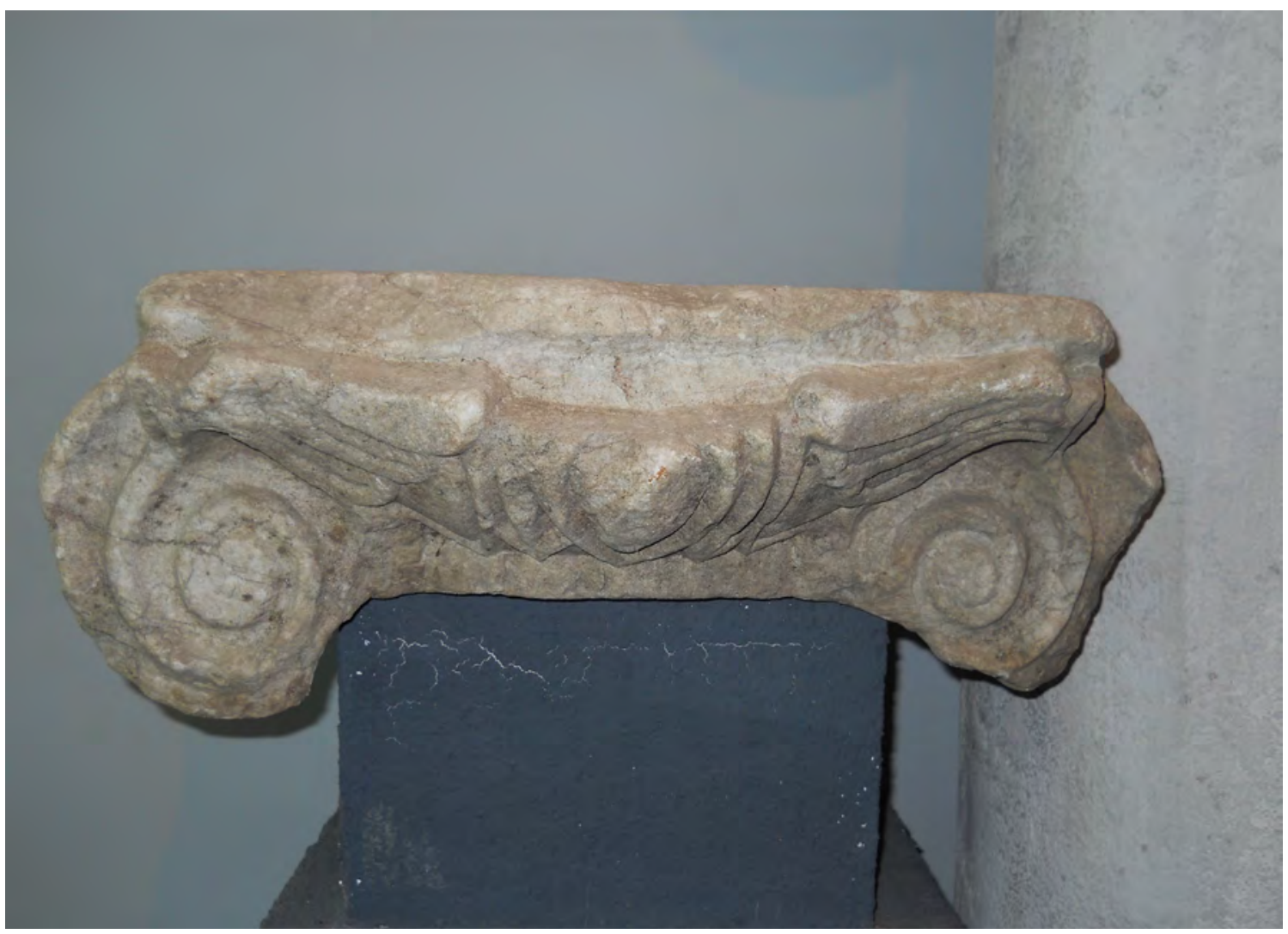

Fig. 8 Ionic capital from Požarevac museum. Photo by the author.

was lost due to the strip-mine "Drmno". Mihailo Valtrović wrote that "all the way into Korabe" there is a twenty minute walk to the eastern city gate heading south-east, but he also wrote that "today, farmers take away the earth for plastering their homes." (Валтровић 1884d:98-99) The Ro-

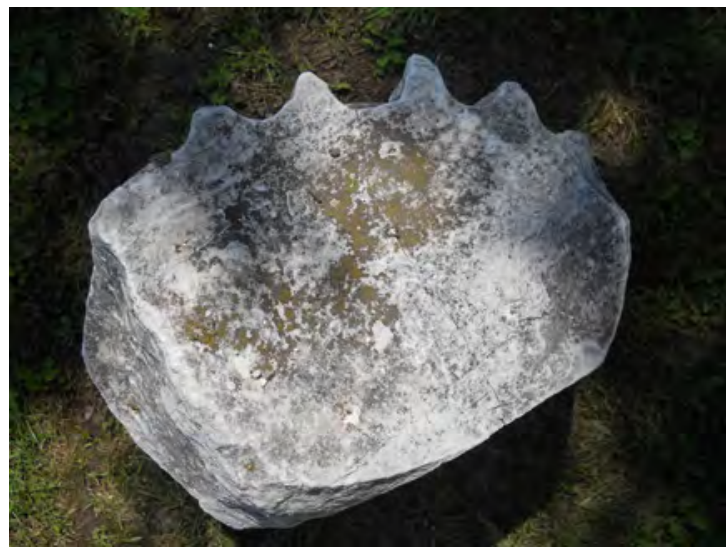
and with plenty of high-quality soil. This information is plausible regarding the vicinity of the

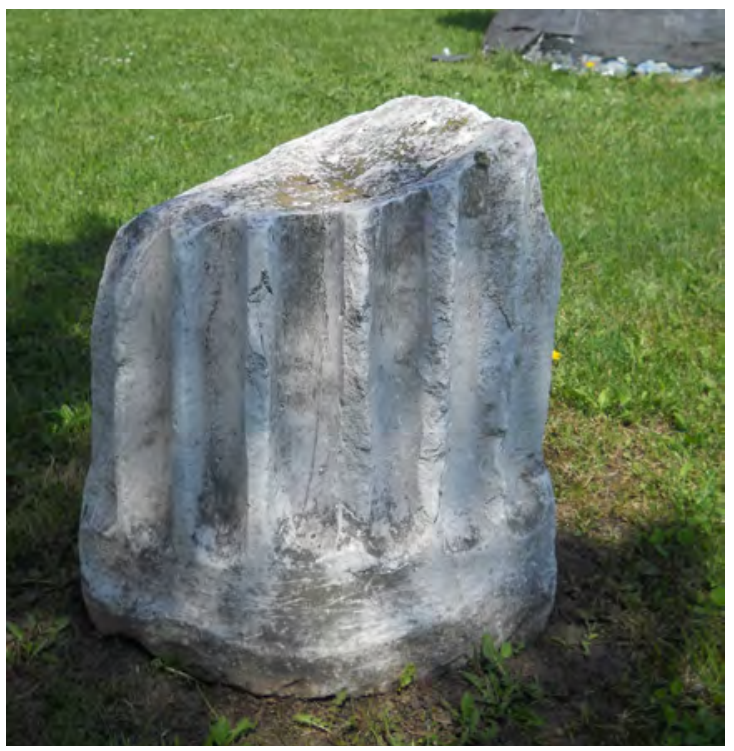

Fig. 9 Shaft of a column with canelures from Požarevac museum lapidarium

mans obtained earth for making bricks and pottery products also from the banks of the river Mlava, which at the time was covered with thick woods craftsmen's centre to the river. (Jordović 1994:96)

The large number of pottery and brick kilns discovered during the excavation of the craftsmen's 


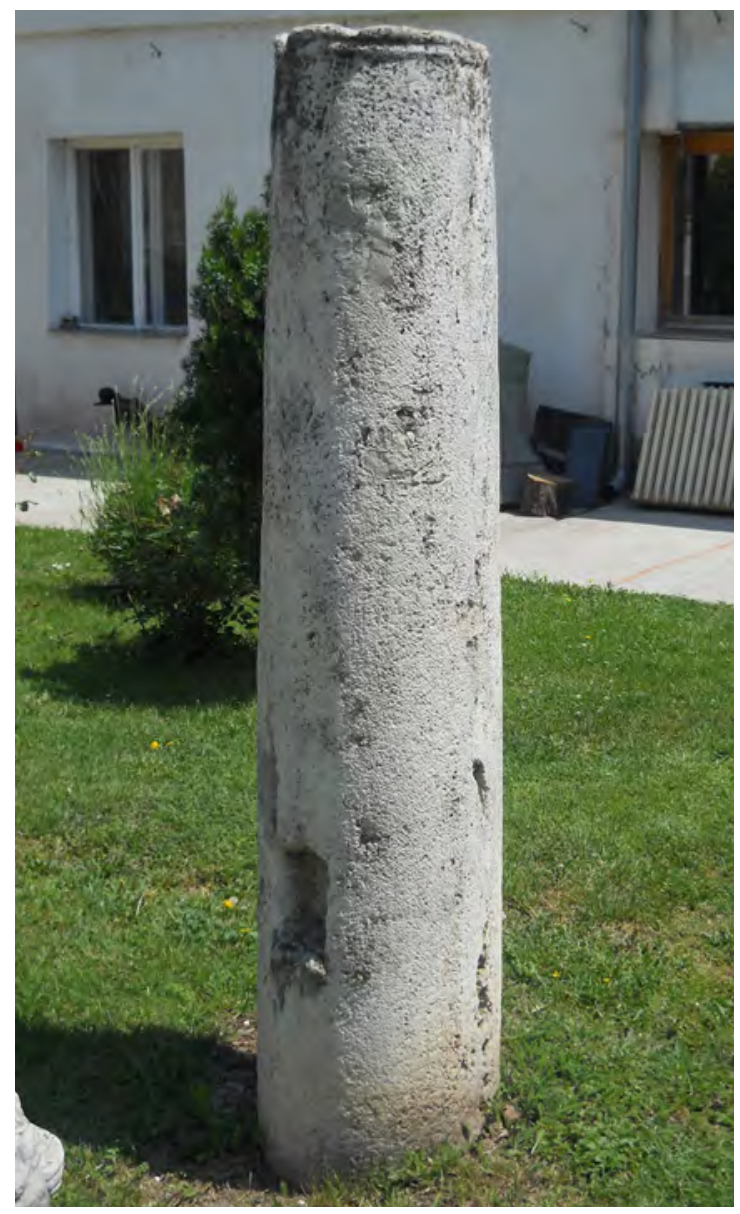

Fig. 10 Shaft of a column from Požarevac museum lapidarium. Photo by the author.

centre testifies to pottery and brick production in Viminacium. Between 1977 and 1992, during the protective research, eleven kilns were excavated, which were used for firing bricks, imbreces and tegulae, as well as fourteen pottery kilns. (Fig. 12) The oldest pottery kiln dates from the $1^{\text {st }}$ century A.D. but the majority date from the $2^{\text {nd }}$ and the $3^{\text {rd }}$ century, and some also from the $4^{\text {th }}$ century. (Jordović 1994:95) The Viminacium brick was important for the building activities in this town, but also in other settlements and fortifications along the Danube limes in Moesia Superior. (Jordović 1994:95) Although brick production in Roman towns was mostly performed by legions, apart from the military production centres, there were also civilian, city and imperial brick factories. In Viminacium, only military brick factories have been discovered so far. (Jordović 1994:95) Owing to the legionary stamps on their products, they can clearly be defined from the rest of the products. (Васић 1907:70, Валтровић 1884c:132, Jordović 1994:95)

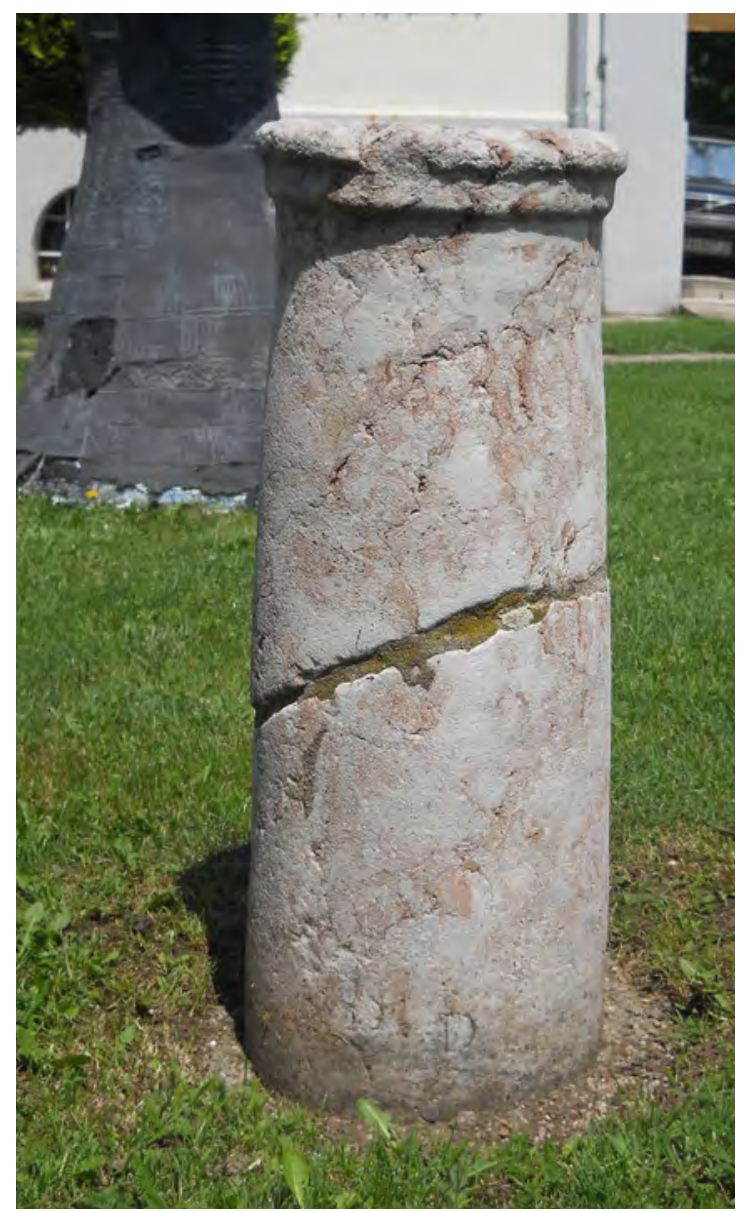

Fig. 11 Shaft of a column from Požarevac museum lapidarium. Photo by the author.

In Viminacium, unbaked brick, ie. adobe was also used for building. Examples of such buildings are brick kilns in the craftsmen's centre mentioned above. (Fig. 13) It is important to mention here a natural product which, with its features, can be described as a "natural brick". (Rădan and Rădan 2012) In the nearby hill, above Stari Kostolac, upon which the remains of the mediaeval town of Braničevo were discovered and in which the coal mine "Stari Kostolac" was operating until 1966, (Вучетић 2010:101) a natural raw material is exploited, known locally as "crvenka" (red clay). As a red earth layer, it can easily be identified in the profile of the hill. (Fig. 14) In the road and wall structures of Viminacium, it can be seen in the form of petrified clay clumps, and as researchers of Margum describe it when they write about structures of this nearby settlement that were also made of this material, it is actually present as" pieces of irregularly shaped loess burned during combustion in a coal layer beneath 
it.” (Марић, 1951, 121) They also mentioned that "such a layer of loess is nowadays encountered in the coal mines of Kostolac and Klenovnik", (Марић 1951:121) which, in the case of Kostolac, actually relates to the aforementioned hill above the village of Stari Kostolac. "Crvenka" cannot be described as a fully geological form and it is known by several different names in the world, such as scoria, clinker and porcelanite (porcellanite, porcelainite) (Bluemie and Jacob 1973:711) and also as cervenice and cervenka in Czech republic. (Geocaching) In the USA, porcelanite is widely spread and used as a concrete agregate for building roads or as decorative stone.( United States. EIS Task Force 1976:183) Scoria is a name widely used for this form, although it is consists of solid red clays and sand. (Rădan and Rădan 2012: 1) Crvenka is often encountered in the buildings on the outskirts of the Viminacium settlement (Golubović, Korać 2008) (Fig. 15) and, as a less qualitative material, it can probably be connected with periods of crisis in Viminacium, during the $4^{\text {th }}$ and the $5^{\text {th }}$ centuries.Today, it is visible in the substruction of the road entering the legionary fortress through its northern gate, built in the second half of the $1^{\text {st }}$ century A.D. (Viminacium) (Fig. 16) It is also found in the substruction of one of the amphitheatre entrances, (Nikolić, Bogdanović 2012 : 43-44) which could indicate that it was used as a cheap and easily accessible building material, but also that it was used in the early phases of the settlement when brick production was not yet well devel-

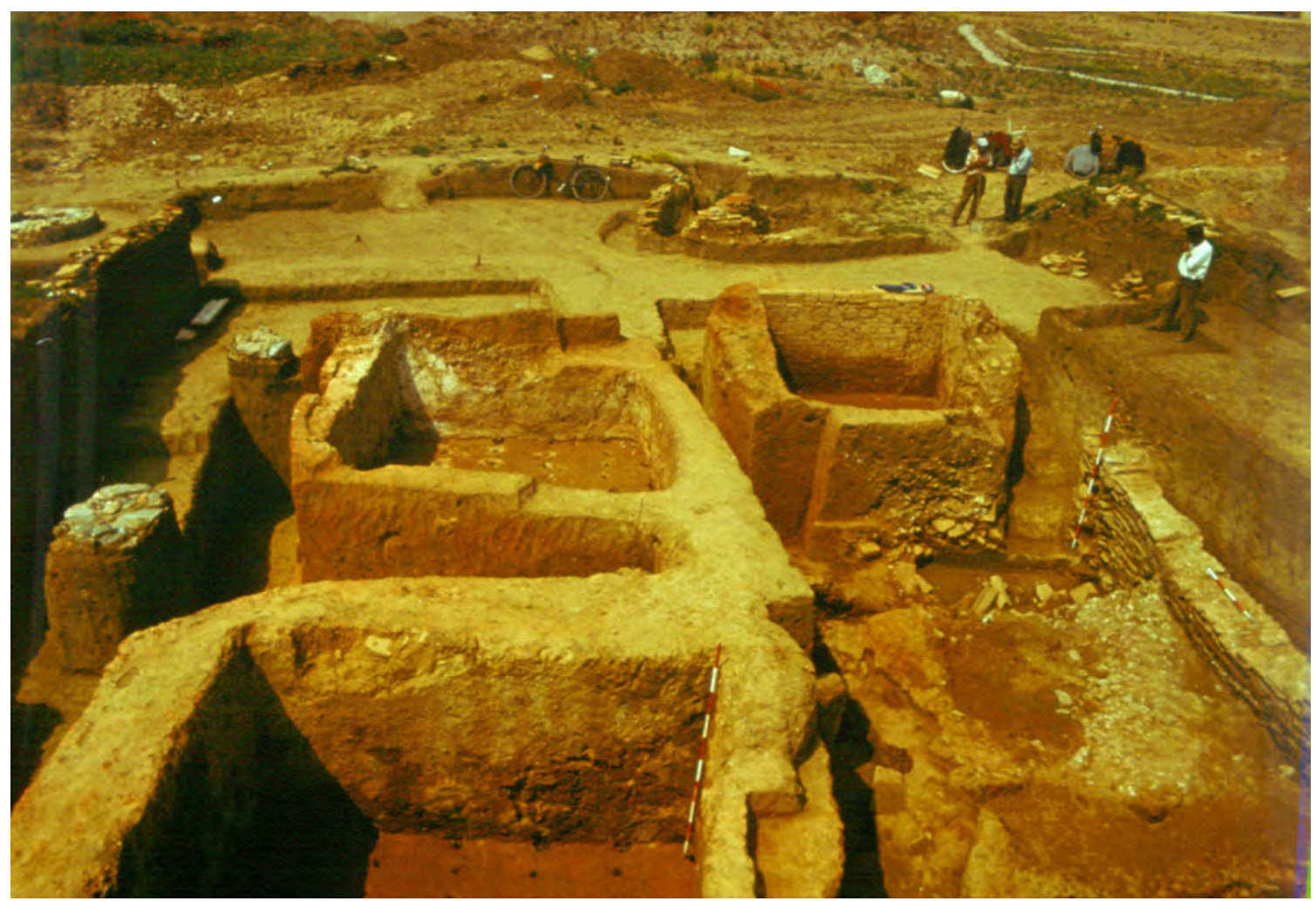

Fig. 12 Brick kils from the craftsmen's centre during excavations. Photo-documentation of the Republic Institute for the Protection of Monuments.

wrong, since scoria is actually related to a volcanic rock, called porcelanite by foreign geologists. In Serbia, this form bears no other name than "crvenka".

Coal, mostly lignite, spontaneously combusts when it comes into contact with oxygen and sunlight, and burns the earth layer above it,".(Rădan and Rădan 2012) and thus forms "crvenka" which oped. This conclusion is supported by the fact that the walls of the nearby Margum, built in the second half of the $1^{\text {st }}$ century, were also made of "crvenka". (Марић 1951:121)

In the beginning of the $2^{\text {nd }}$ century A.D, along with the development of Viminacium, the use of fired bricks in its buildings suddenly grew. (Jordović 1994: 105) The greatest number of the 


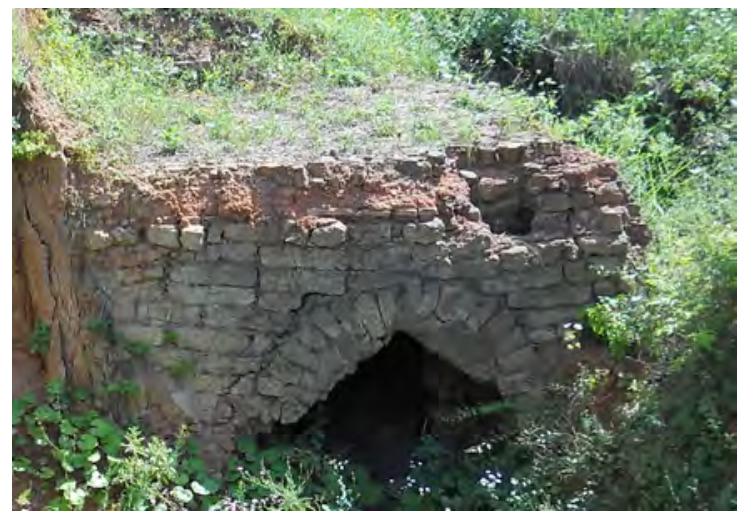

Fig. 13 Brick kiln built of adobe. Photo by the author.

brick kilns excavated so far belongs to this period Ever since then, bricks were commonplace in forming wall faces or the wall cores with mixed material, leveling courses and whole wall structures as an independent building material and also as an pozzolanic additive to lime mortar.

The Viminacium bricks were of different sizes. (Васић 1907:69-70, Валтровић 1884c:131-132) In the wall structures, one most often encounters rectangular bricks, (Fig. 17) while paving was performed with square, rectangular, butterfly-shaped or hexagonal bricks. (Fig. 18) Arched wall-openings were also formed with bricks and the majority of grave constructions (Fig. 19) and their vaults (Fig. 20) were also built of bricks.(Милошевић 2006)

\section{Mortar}

Lime mortars used in Roman civil engineering were made according to a recipe specifying both their content and mix ratio. Depending on the type and accessibility of the materials necessary for producing mortar, mortar features differed from region to region.

There is a hypothesis that on the outskirts of the Roman Empire only non-hydraulic mortars were used. (Ringbom, Hale, Heinemeier, Lindroos, Brock 2006) Among the results of laboratory analyses of Viminacium mortars taken from the amphitheatre structures, there is no precisely defined hydraulics which would confirm or deny

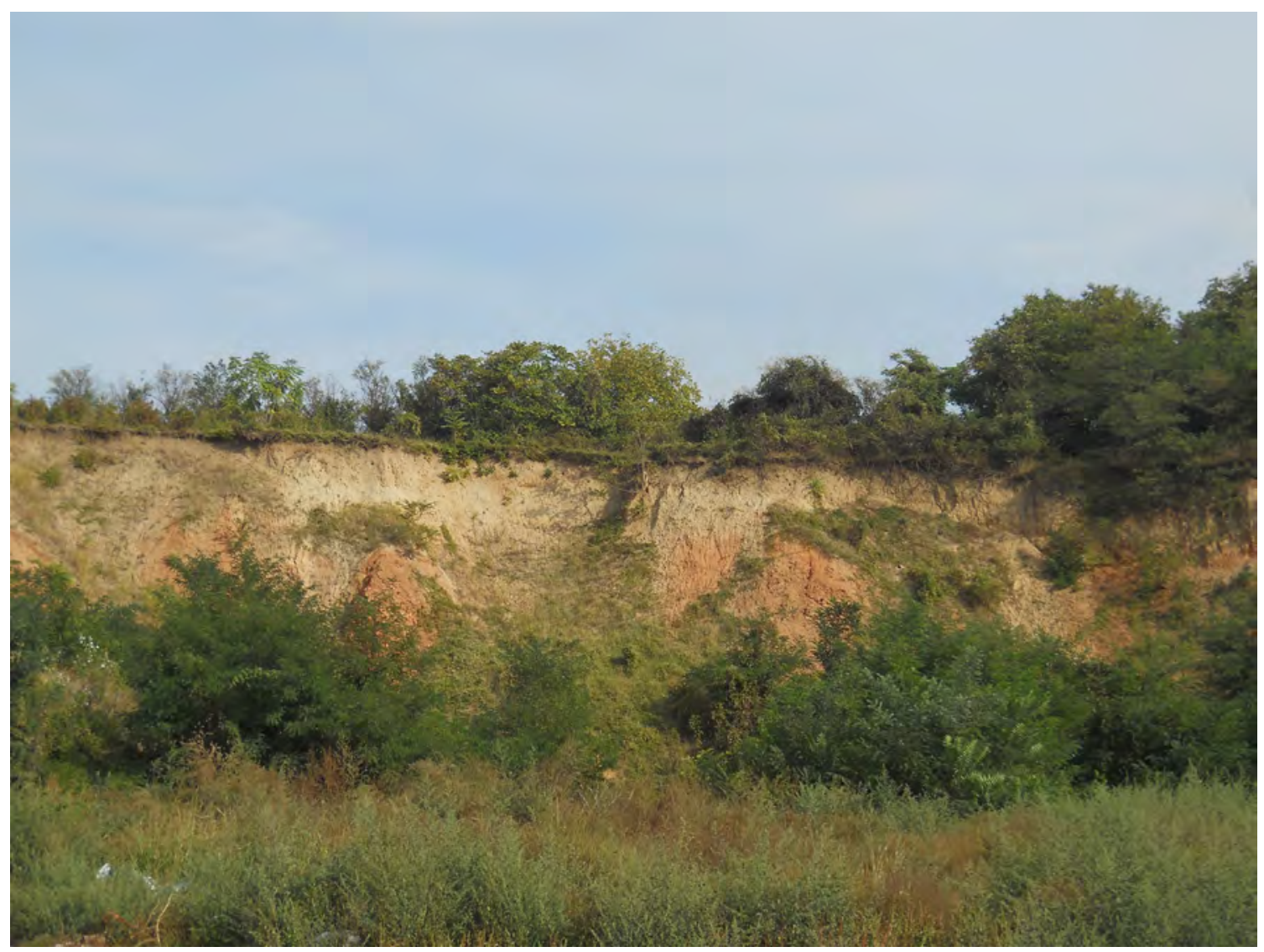

Fig. 14 Hill above Stari Kostolac village with visible red layer of „crvenka“. Photo by the author. 


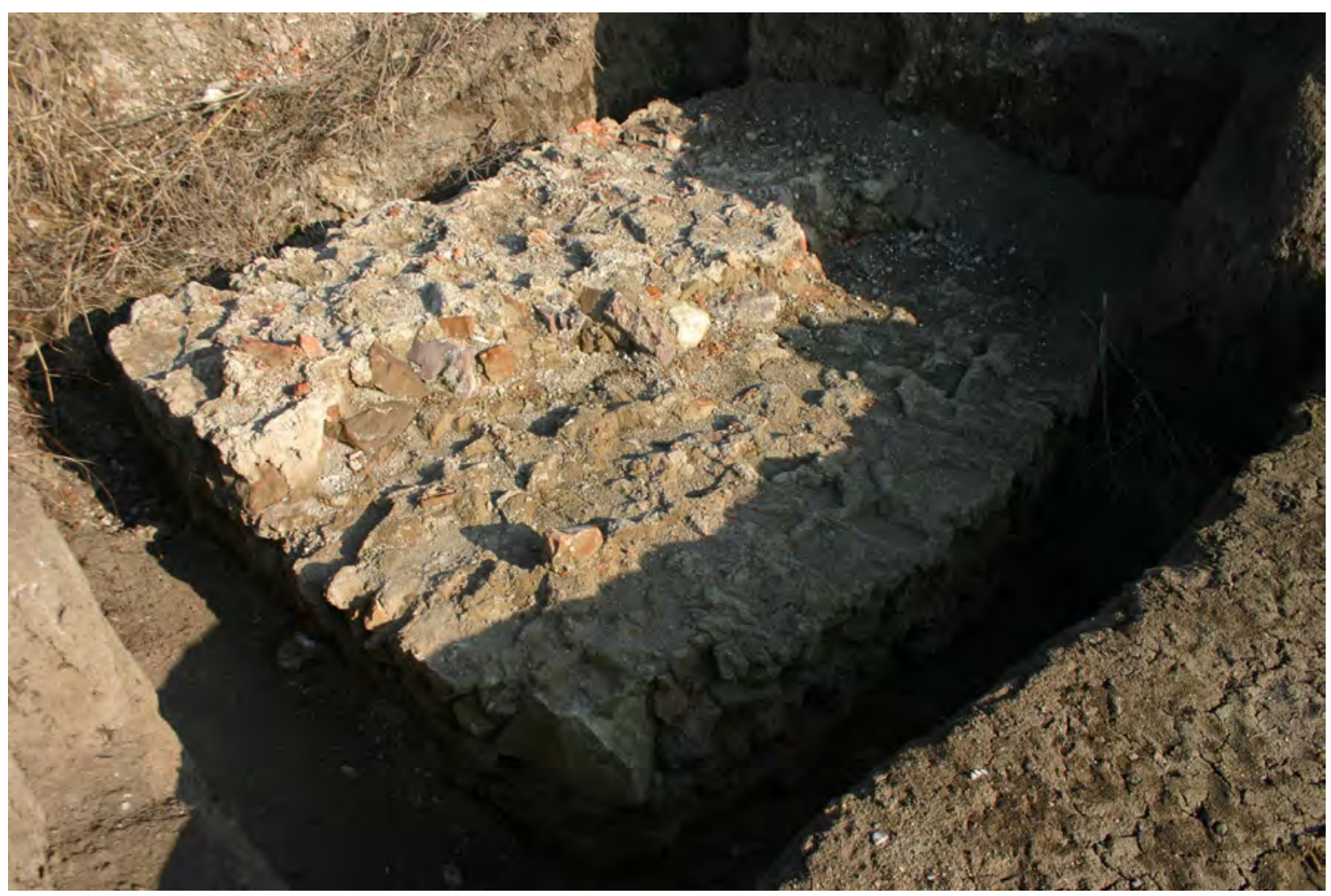

Fig. 15 Foundation structure from the bulding in the temple complex with visible „crvenka“. Golubović, S., Korać, M., 2008

this. (Delić Nikolić I., Miličić Lj., Vušović O., Savić, M., Ivović, B. 2011) After becoming acquainted with ancient mortar recipes and the idea of hydraulicity, comparing them with modern research (Moropoulou, Bakolas, Bisbikou 2000:4558, Maravelaki-Kalaitzakia, Bakolas, Moropoulou 2003:651-661) and analysing values obtained after the laboratory examination of the Viminacium mortars, (Delić Nikolić I., Miličić Lj. , Vušović O., Savić, M., Ivović, B. 2011) certain conclusions can be drawn regarding its probable hydraulicity, which can be found in a material with pozzolanic features.

There is no research regarding possible natural materials with pozzolanic features used for Roman architecture in the territory of Serbia, including Viminacium. However, the aforementioned laboratory analyses of the amphitheatre mortars, and the existence of volcanic and zeolithic tuffs in the areas of Serbia, (Andrić 2010:189-202, Andrić, 2011, 190-230) can represent a starting point for future research.

In modern times, volcanic tuff is not exploited in Serbia, although there are several beds and it is possible to continue with the exploitation in the Vranje valley. Zeolith is a mineral of sediment rock - zeolithized tuff, and it is nowadays exploited in the Vranje valley, further on, near Kruševac, Brus etc. So far, though, there have been no traces found of any kinds of exploitation of tuff quarries in ancient times in Serbia. The research at hellenistic site Kale in the village Krševica, in the southeast of Serbia, dated to the period from the 3rd to the 4th century B.C., revealed the structures built of tuff. Its possible deposit is $10 \mathrm{~km}$ to $15 \mathrm{~km}$ away from Krševica, and 5km away from Vranje, but the traces of ancient quarry have not been discovered yet.(Popović, P. 2008: 101-102).It is interesting to mention the bed of zeolithized tuff in the village of Slanci on the Danube, few kilometers east of above mentioned Višnjica which can be a possible place for ancient exploitation of Viminacium construction purposes.

As artificial materials with pozzolanic features, brick and pottery fragments can be found in mortars of all Viminacium buildings. They were used either minced or crushed. In mortars used for building and core walls filling, brick is visible in the form of larger or smaller fragments, while in the mortars used for plastering and for finishing floor layers, brick is incorporated as a powder which mixed with sand and lime gives the mortar its red colour.(Fig. 21, Fig. 22) 


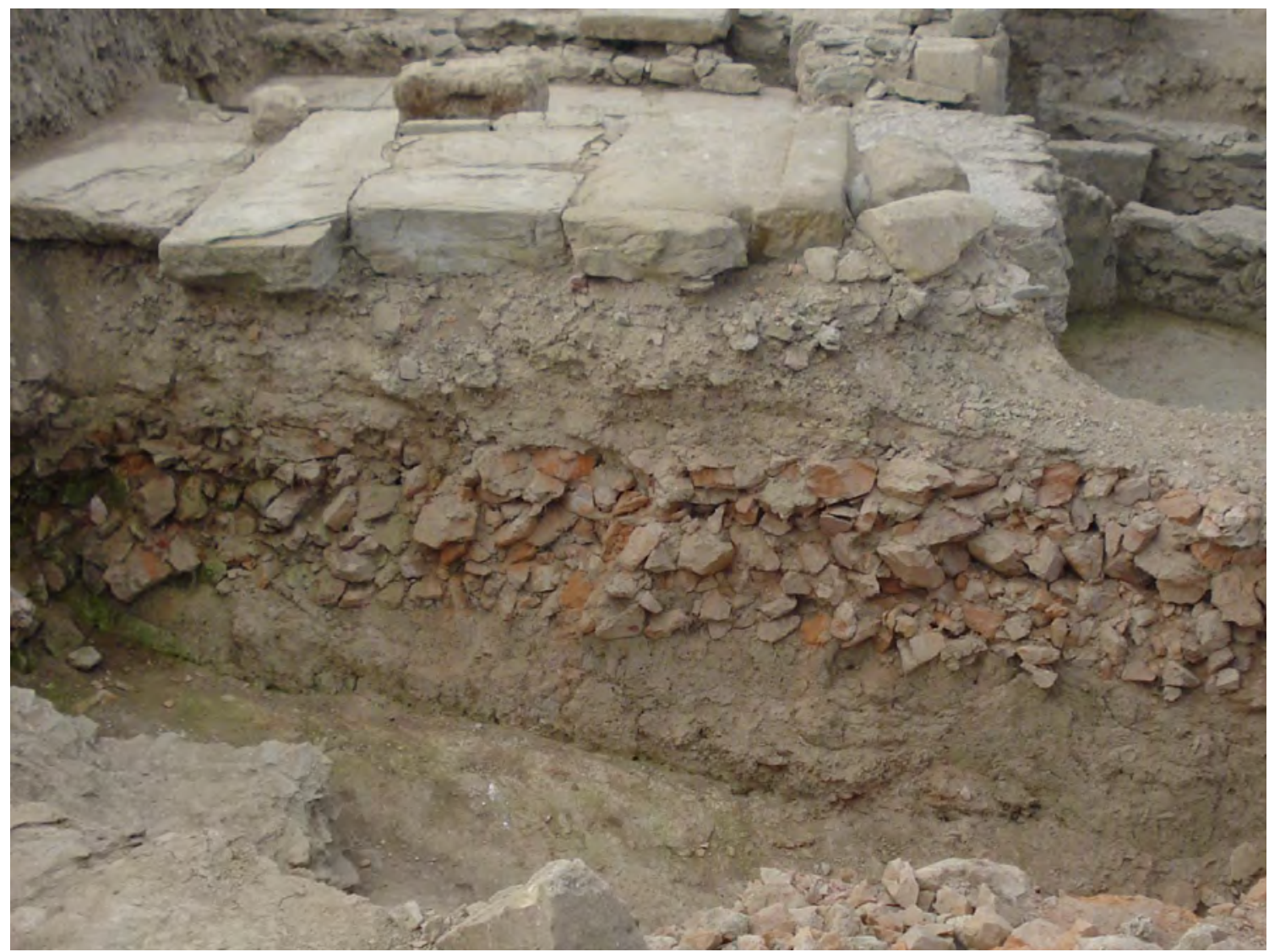

Fig. 16 Substructure of the road entering the northern gate of the legionary fortress. Photo by the author

Nevertheless, not all of the bricks possess pozzolanic features. These features exist only in bricks baked at temperatures lower than $950^{\circ} \mathrm{C}$, with a high percentage of clay and with certain chemical features, (Pinheiro, Montenegro, Gumieri 2010) which all can be related exactly to the Viminacium ones. Actually, The Viminacium bricks, as well as all the other ancient

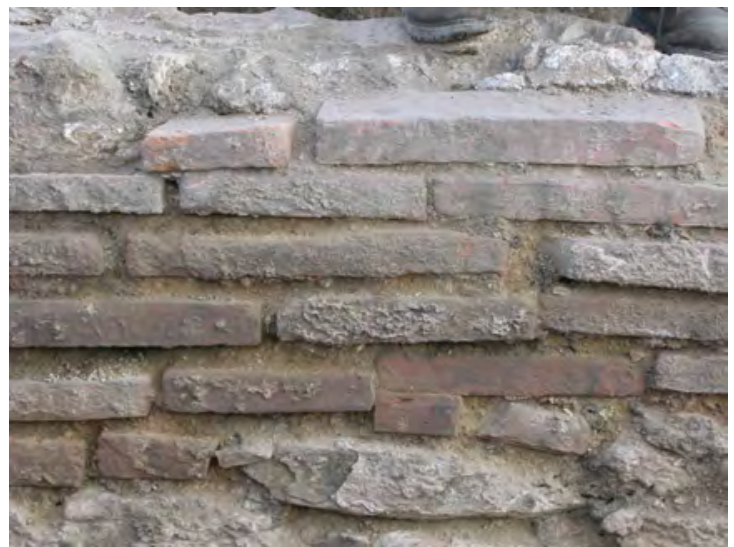

Fig. 17 Opus testaceum of Viminacium thermae wall. Photo by the author.

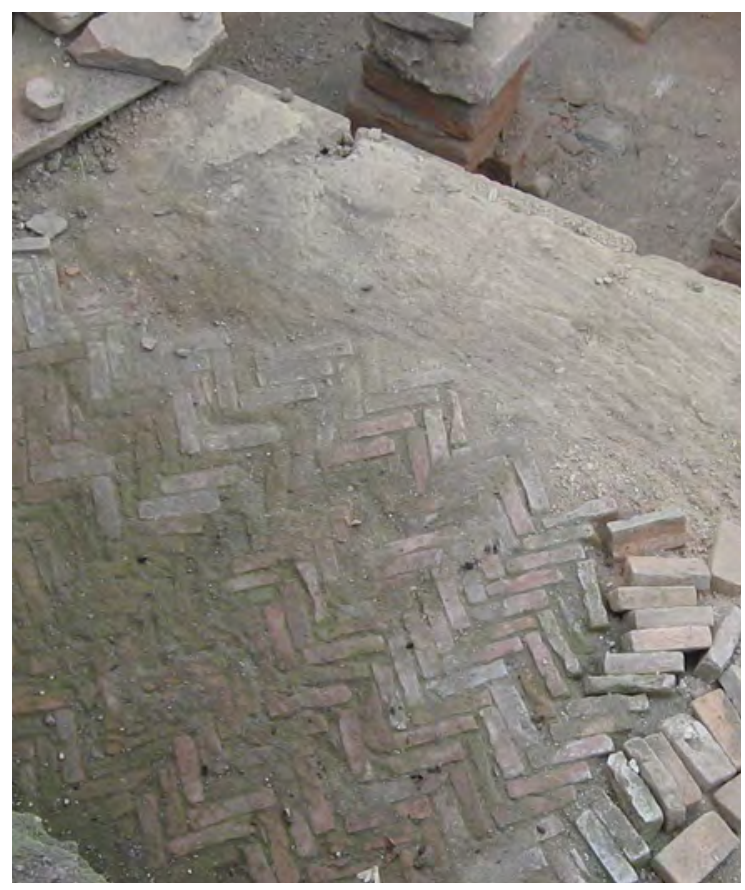

Fig. 18 Brick pavement in Viminacium thermae. Photo documentation of the Project Viminacium, Archaeological Institute Belgrade 


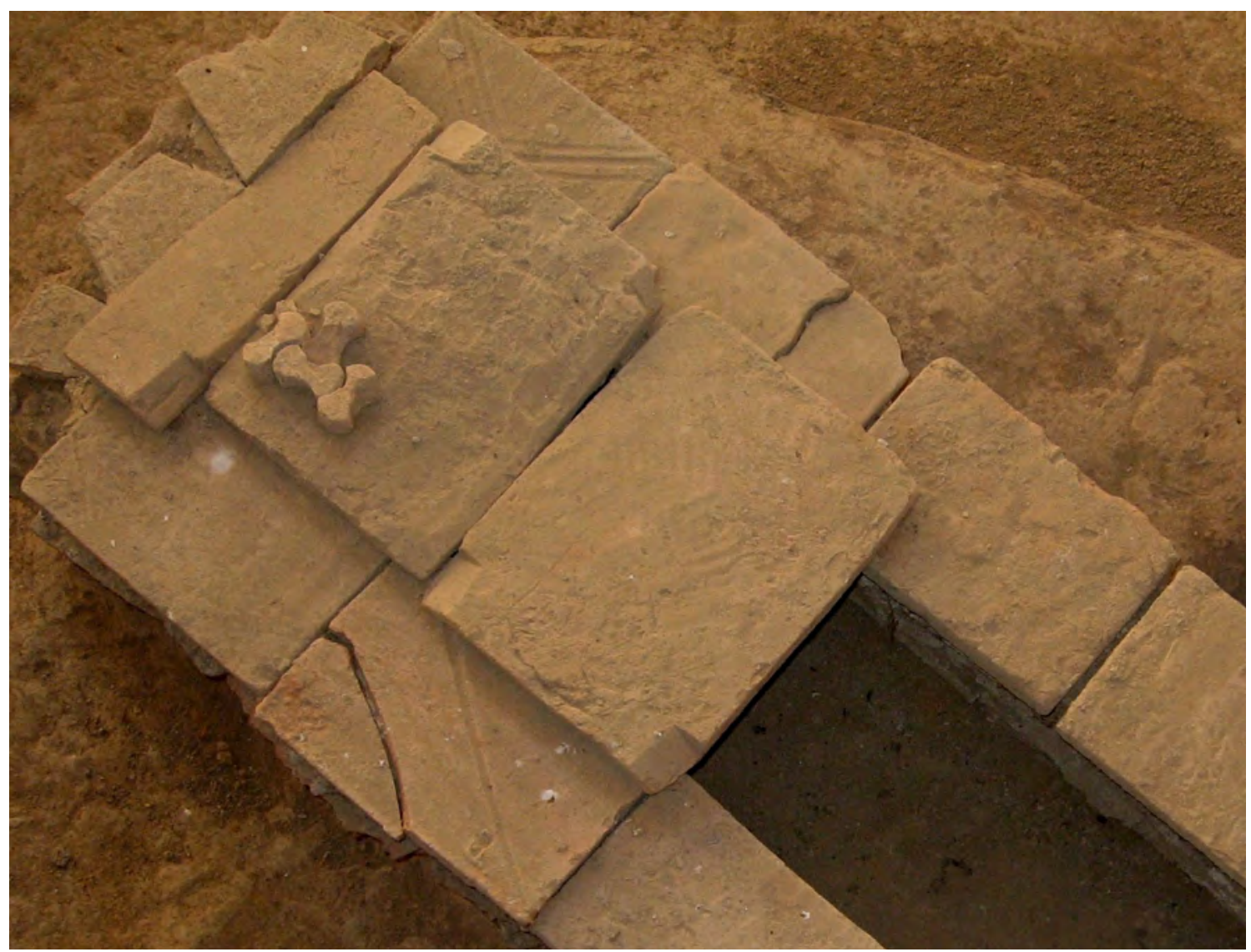

Fig. 19 Grave from “Pirivoj” necropolis in Viminacium built of bricks. Photo by the author.

bricks from the territory of modern Serbia, were fired at a temperature of up to $800^{\circ} \mathrm{C}$. (Radivojevic, Kurtović-Folić 2006:697, Radivojević 2004:34). Also, the overall percentage of certain oxides in Viminacium bricks (Raičković, A. 2012, tabs.2-8) is matching to the one needed for the material with pozzolanic features.

Nevertheless, laboratory analyses of mortars from the Viminacium amphitheatre show that some of the mortars without brick additives, which was also easily visible, (Fig. 23) still possess great strength and high values of aluminium and silicon oxides compared to the ones containing these additives. This most likely means that, while preparing mortars, the builders of Viminacium often used minced or crushed brick as an additive to an aggregate, but also some other, most likely natural mineral aluminosilicate additives, which would have very much improved the mortar features. (Delić Nikolić I., Miličić Lj., Vušović O., Savić, M., Ivović, B. 2011, Nikolić, E., Bogdanović, I. 2012: 59) The possible use of "crvenka" also belongs to the study of natural materials with pozzolanic features which could be used for producing the Viminacium mortars. Worldwide research showed that it can possess pozzolanic characteristics (Gutt, Gaze 1975: 439-450), actually that "naturally burned clay, often present in coal mines", can be possible mortar additive, (Jevtić, Zakić, Harak 2002:60) which probably means that the red colour of the Viminacium mortars could have been derived either from brick additives or from "crvenka".

Apart from lime mortar, the builders of Viminacium also used mud mortar as a binder. It was combined with brick for building pottery kilns (Jordović 1994: 99-101), with stone and brick for tomb constructions, (Васић 1907:70) and was probably used in the walls of the oldest Viminacium buildings.

During the early phases of the legionary fort and the city, wood as a building material was also used, evidence of which is found in holes for wooden piles holding up the wooden stands of the Viminacium amphitheatre (Nikolić, Bogdanović 2012: 43-44, Valtrović 1884:102), and also the remains of the wooden architecture of some other buildings.(Kondić. Zotović 1973:96) 


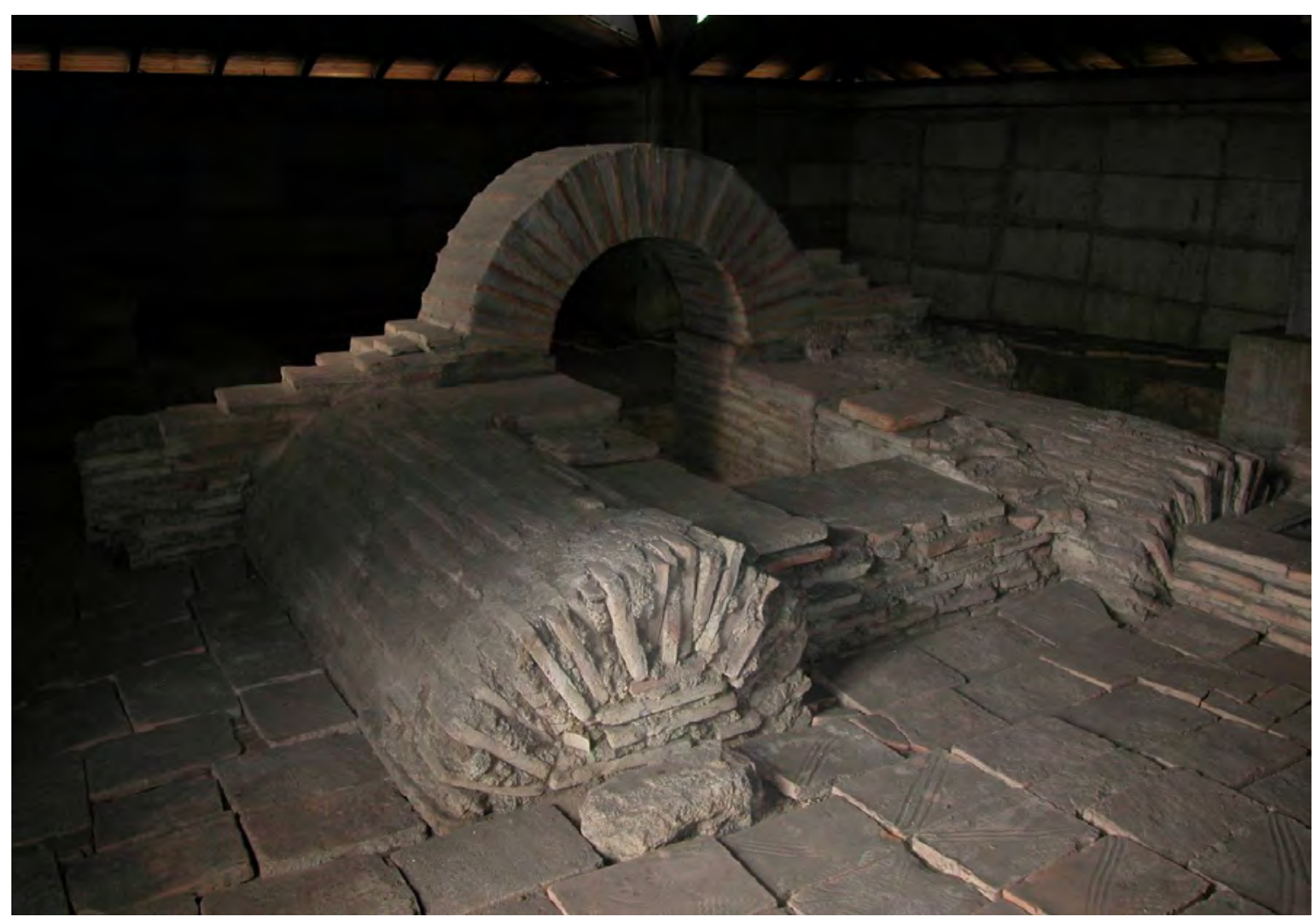

Fig. 20 Vaulted tomb from Viminacium necropolis „Pećine“ built of bricks. Photo by the author.

\section{BUILDING TECHNIQUES OF THE VIMINACIUM BIULDINGS}

As in all the other parts of the Roman Empire, the most commonly used building technique in Viminacium was opus mixtum - a technique in which a mixture of stone and bricks was used, actually its subgroup, known as opus incertum mixtum. Although today one can no longer speak about the upper parts of monumental Viminacium buildings, it is presumed that, because regularly cut stone blocks were unavailable, all of the techniques demanding such a building material were less frequently used. Therefore, according to the Viminacium buildings examined, apart from the already mentioned opus mixtum technique, other techniques such as opus incertum and opus testaceum were also used. Big buildings were also made using the opus quadratum technique. Also, there are a few examples of buildings using the opus spicatum technique.

The opus mixtum technique used in the territory of modern Serbia, including Viminacium, was formed during Late Antiquity under influences from the eastern part of the Empire and it can, therefore, be called the "Byzantine" opus mixtum. (Radivojevic, Kurtović-Folić 2006:693)
Even though brick as an artificial material with pozzolanic features was added, lime mortar was never able to reach the quality of mortar with added natural materials with pozzolanic features. This led to changes in building techniques in all of the places where such natural materials were not available. (Radivojevic, Kurtović-Folić 2006:693694) Therefore, stone and bricks were given more importance in supporting structures themselves. Instead of a strong core of "Roman concrete" structura caementicia, typical for traditional Roman architecture, owing most of its good features to qualitative mortar, in the territory of the Eastern Roman Empire there was a strong core of crushed material bound with lime mortar, the so-called "trpanac", with stone and brick playing very important roles. (Fig.24a, Fig.24b) (Radivojevic, Kurtović-Folić 2006:693-694) Since no stone suitable for cutting into blocks was available in the area of Viminacium, roughly cut stones were mostly used not only for wall cores, but also for wall facings. In such a technique, brick was mostly used as a levelling course, but also where support for another constructive element or a precise wall ending was needed. When walls were thinner, brick layers were placed through the entire cross-section of the 


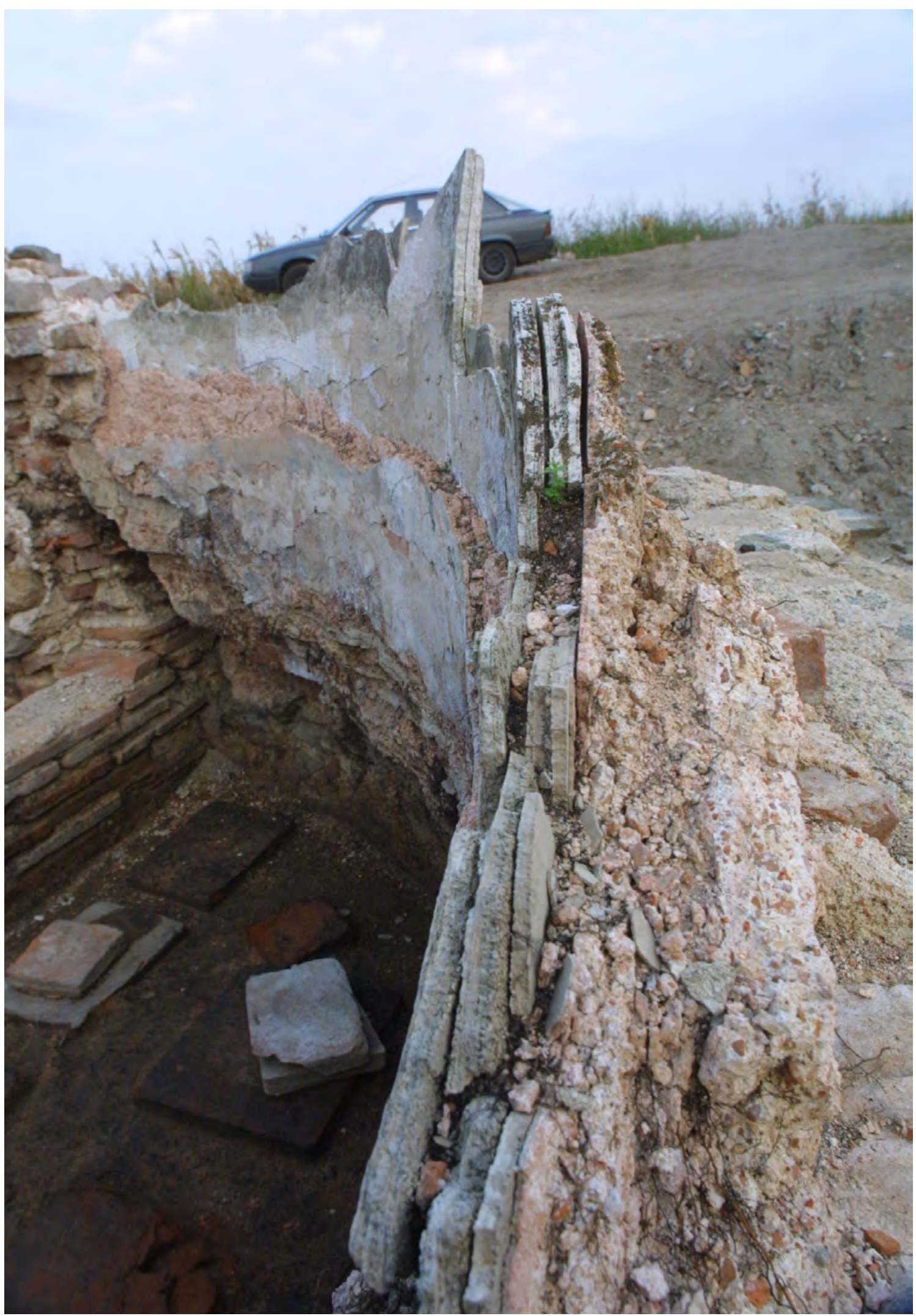

Fig. 21 Lime mortar for plastering of the thermae walls with the addition of brick. Photo documentation of the Project Viminacium, Archaeological Institute Belgrade. 


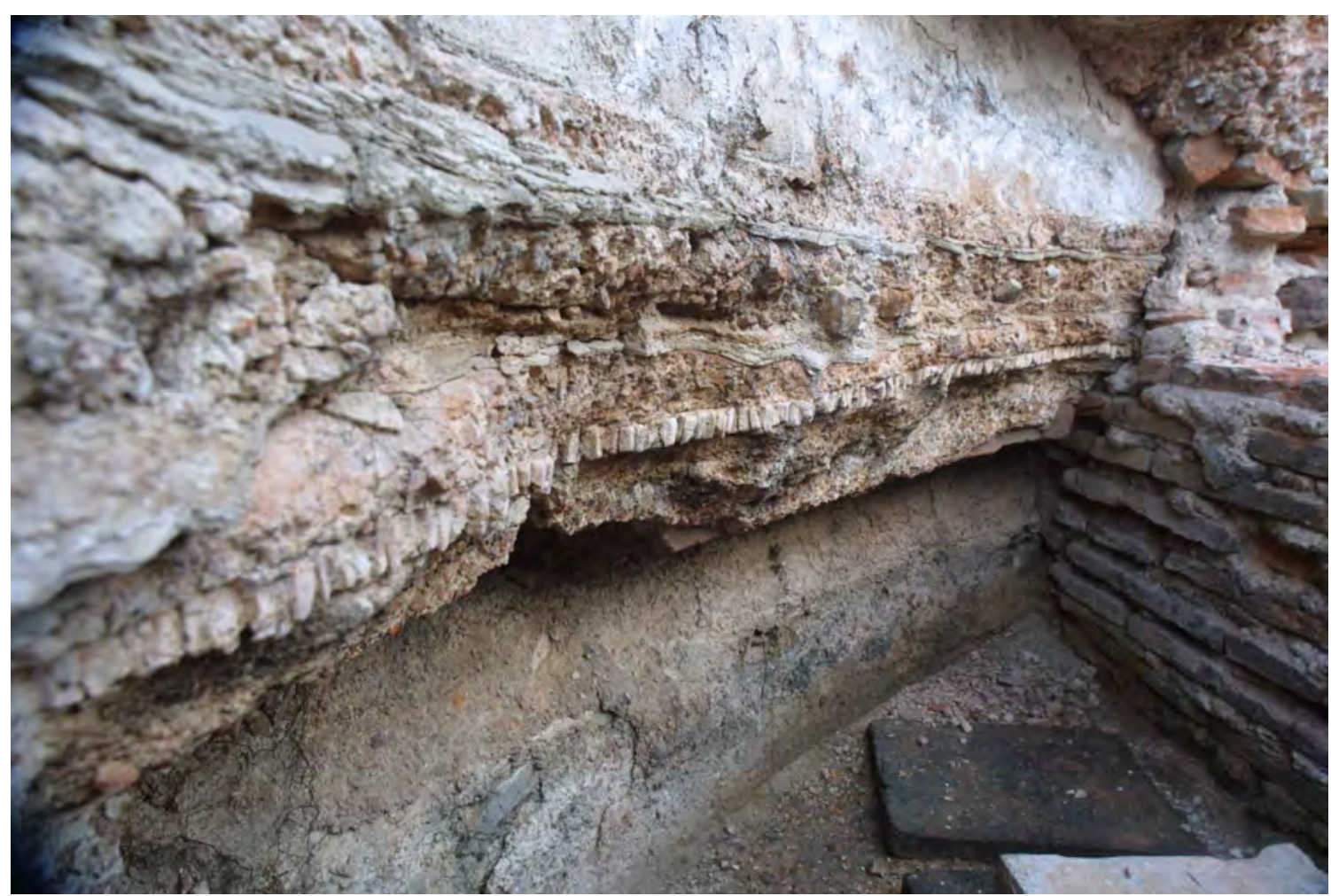

Fig. 22 Lime mortar for floor layers of the thermae with the addition of brick. Photo documentation of the Project Viminacium, Archaeological Institute Belgrade.

wall. When vaulting, the upper building parts were probably always made of brick, which can be observed in the preserved Viminacium tombs.

Walls of lower and underground parts or foundations of Viminacium buildings were almost always made using the opus incertum technique. However, it is certain that some of the foundations were built out of stone blocks, as mentioned by Mihailo Valtrović, the first Viminacium explorer, who wrote that the "foundations of some of the buildings were very deep and made of large stone blocks". (Валтровић 1884c:95)

Due to the appearance of locally found schist, the upper parts of the Viminacium buildings made in the opus incertum and opus incertum mixtum technique were probably plastered, which can be actually seen on the walls of excavated thermae building. (Fig. 26) Nevertheless, even though stone that could easily be cut into blocks was not locally available, it can be assumed that the walls of some of the important buildings, apart from those using the opus quadratum technique, were also built in the opus vittatum mixtum technique in order to obtain a decorative effect when there was no mortar as a finishing layer.

Walls made completely of stones bonded with lime mortar, in the inconsistent not careful- ly build opus quadratum technique, but which still followed the rule of placing headers and stretchers, with smaller holes filled in with small pieces of stone and bricks, can be observed in the arched arena wall of the amphitheatre building,(Fig. 27a, Fig.27b, Fig.28a, Fig.28b, Fig.29) dated to the period between the first quarter of the $2^{\text {nd }}$ century A.D. and the beginning of the $4^{\text {th }}$ century A.D. (Nikolić, Bogdanović 2012: 44) The same case of filling in spaces between large stone blocks is encountered in the walls of ancient Doclea. (Živanović, Stamenković 2012:126-127) Technique opus quadratum in the Viminacium amphitheatre is used as a combination of two methods. The first is a mutual alternation of the rows of headers and stretchers, typical for walls built without a bonding material. The second is an alternation of headers and stretchers in each row, in this building they were placed with no specific pattern. The irregularity of both of the methods is reflected in different block heights. (Radivojević 2004:49-50, Acocella 2006:67, Adam 1999:206-207) The same way of performing the opus quadratum technique is encountered in the already mentioned walls of Doclea. (Živanović, Stamenković 2012:126-127) Some parts of the arched wall were irregularly built of fragmented bricks 


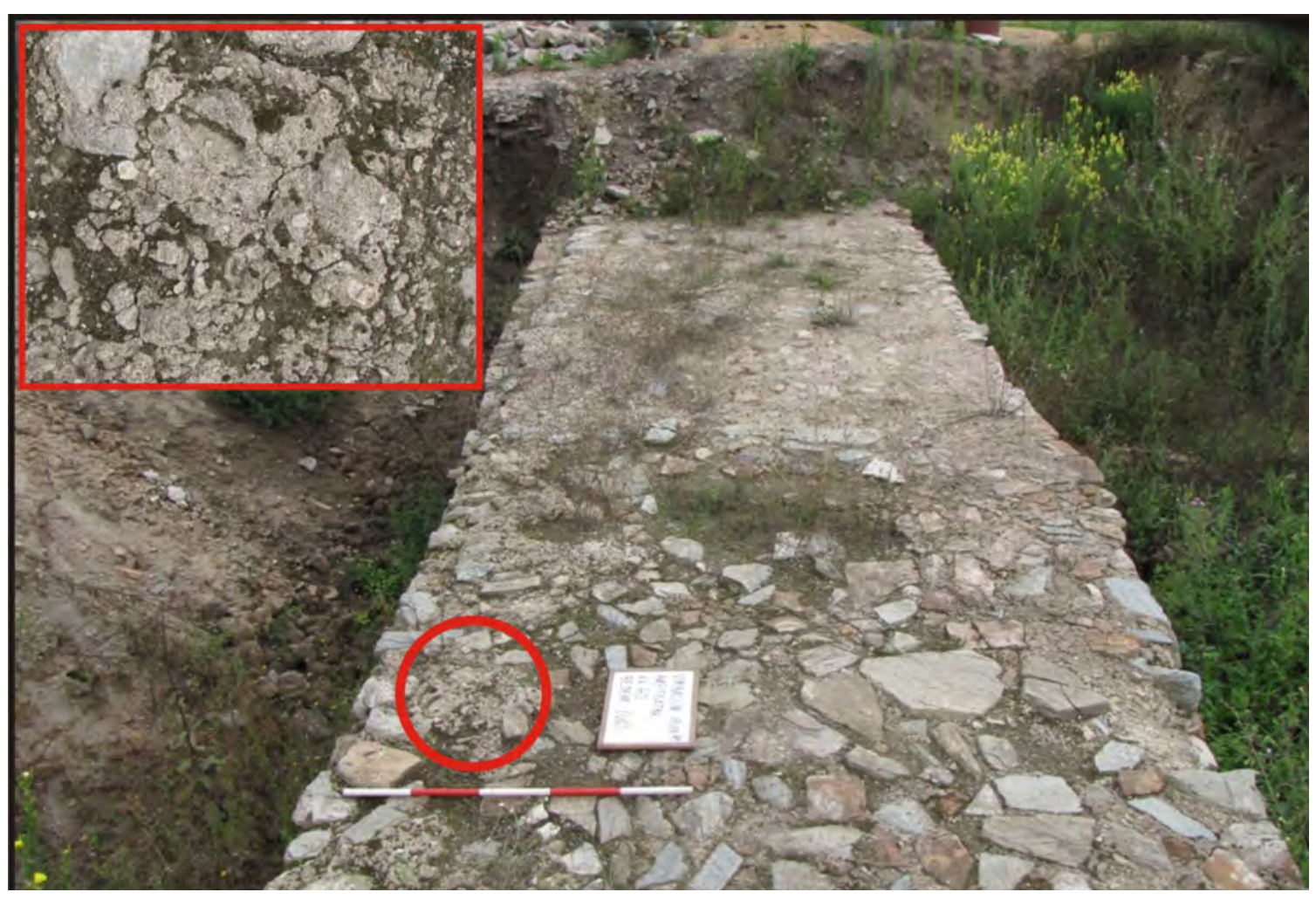

Fig. 23 Wall of the city rampart with the picture of the hard lime mortar without addition of brick. Photo documentation of the Project Viminacium, Archaeological Institute Belgrade.

and schist , most likely due to some later repair of the wall which, for some reason, had collapsed and for which the material originating from some ruined buildings was used. (Fig. 28a) A lack of money and time or an inability to obtain the same stone blocks for repair, after a collapse, fire, war damage or something similar, led to a wall repair of this kind. Examples of such filling in of destroyed walls can be seen in Pompeii, where after the earthquake, walls were filled in using different techniques and with different materials from the ruins and pottery. (Adam 1999:307-309) In other walls of the amphitheatre, built-in parts of architectural plastic and tombstones can be seen, as well as stone construction parts from the other buildings, actually spolia,, which can also be seen in wall of Doclea. (Živanović, Stamenković 2012:127)

It can be presumed that great Viminacium buildings were constructed with massive walls, like the fort and the amphitheatre, actually the first public buildings, in the opus quadratum technique. Still, in the amphitheatre, most likely due to lack of limestone blocks, the builders also used the opus incertum technique wherever it was possible. All of the rooms around the arena were built from schist using this technique and only the corner supports were made of limestone blocks. (Fig, 25) Regarding the city walls, their northern part, preserved up to a height of $2.25 \mathrm{~m}$, was examined several decades ago, and showed that it was built "of cut blocks bound with mortar". (Zotović 1974:48)

Building with large stone blocks can be linked to the greatest prosperity of Viminacium in the $2^{\text {nd }}$ and $3^{\text {rd }}$ centuries. Although they were massive structures, early Byzantine walls at the site of "Svetinja" were built out of broken stone pieces and bricks with lots of mortar. They were also built out of the aforementioned stone blocks derived from ancient ruins, but only in the layer of socle. (Popović 1987:432-445) During the first research of Viminacium in 1882, Mihailo Valtrović found a round fort tower preserved up to $1.60 \mathrm{~m}$ with walls which were $2.30 \mathrm{~m}$ thick, made of "cut and uncut stones". (Валтровић 1884c:95) He also wrote about great stone blocks, $3.0 \mathrm{~m}$ long and $0.50 \mathrm{~m}$ thick, used to pave a street. (Валтровић, 1884c, 99) what can be connected to usage of large limestone or sandstone blocks, but also to large schist blocks which is the case with recently excavated street in Viminacium. (Fig.30a) and the road leading through the northern gate of Viminacium fort.(Fig. 30b) 


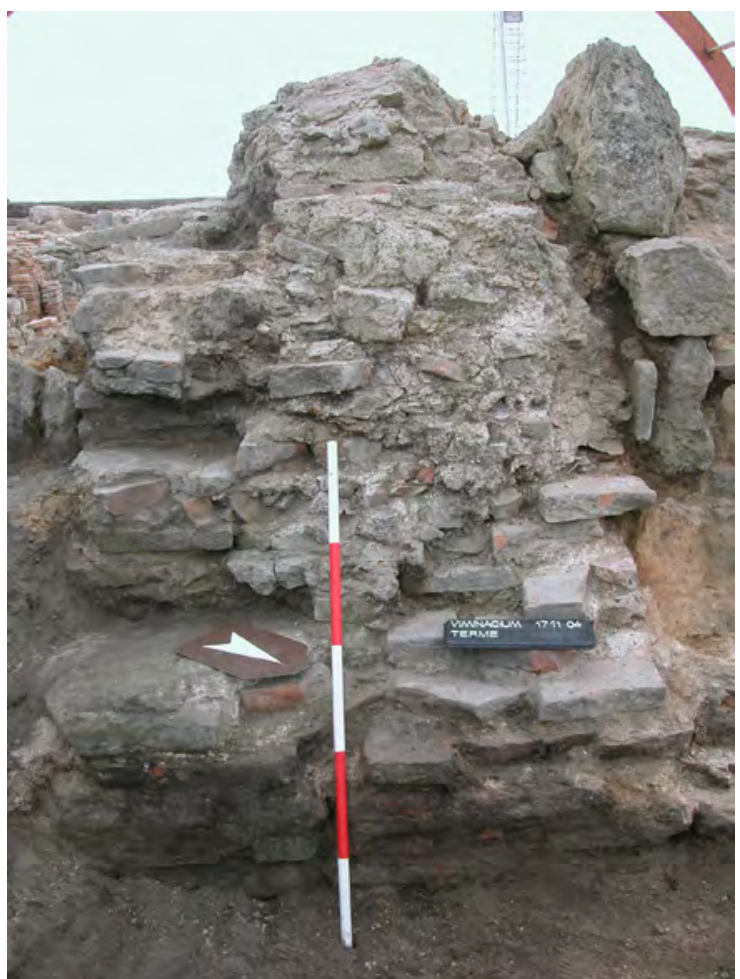

Fig. 24a Trpanac in the wall of Viminacium thermae. Photo documentation of the project Viminacium, Archaeological Institute.

With the exception of stone sarcophagi made of limestone and sandstone, which can be seen exhibited in archaeological park of Viminacium and lapidariums in Požarevac and Belgrade, single graves from Viminacium mostly represent constructions made of bricks, sometimes mixed with small stone pieces, ${ }^{1}$ although huge grave constructions made of schist were also discovered. " "In the very vicinity of Viminacium there is no stone suitable for cutting. Therefore, the graves known so far were mostly made of bricks, for which there was a lot of suitable clay".(Валтровић 1884d:124) This is what some hundred and thirty years ago, Mihailo Valtrović wrote. Over 13,000 graves excavated later in Viminacium (Golubović 1999:9), proved him right.

Apart from the opus mixtum technique, Late Antique architecture of the Eastern Roman Empire also included walls entirely made of bricks, in a technique which can be called "Byzantine" opus testaceum This is different from the opus testace-

1 About the types of grave constructions and materials used for their building see in: др Милоје Васић, „Неколике гробне конструкције из Виминацијума“, Старинар н.р. II (Београд: Српско археолошко друштво, 1907), 67.

2 Ascertained after looking into the field documentation of the project Viminacium of the Archaeological Institute. um technique which includes walls plastered with bricks and filled with "Roman concrete". (Radivojevic, Kurtović-Folić 2006:693-694) It is presumed that in Viminacium, owing to own brick production and accessibility to clay sources, the "Byzantine" opus testaceum technique was frequently used in upper wall structures. The role of bricks was certainly very important in the construction of buildings, forming their skeletal structures in most cases, with schist used for filling.

An example of the change of building techniques through phases of a building can best be observed in the Viminacium baths, dated to the period from the $1^{\text {st }}$ to the $4^{\text {th }}$ century. (Zotović 1973:47-50, Kondić, Zotović 1974:94-98, Milovanović 2008: 51-55) Here we encounter the techniques opus incertum, (Fig.31) used for constructing the foundations and undeground walls, and opus testaceum, opus incertum mixtum and opus mixtum for the upper parts of the building. Soon after the earliest research of the baths, it was evident that there were

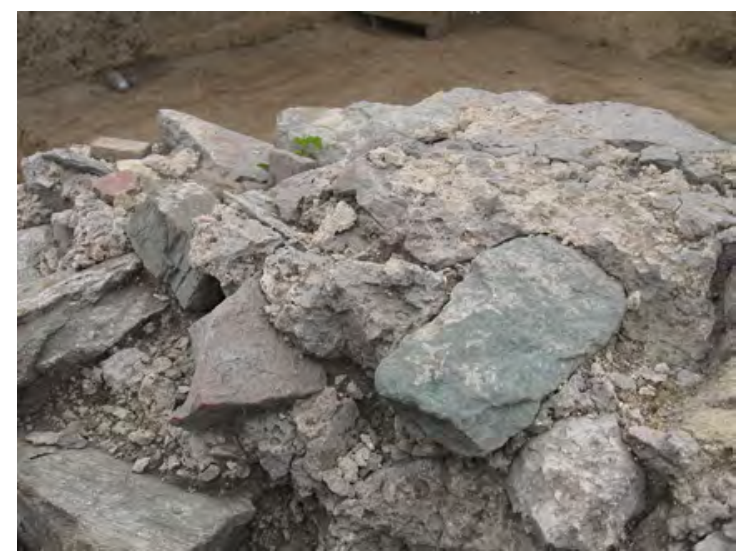

Fig. 24b Trpanac in the arched arena wall of the Viminacium amphitheatre. Photo by the author.

three phases of existence, (Kondić, Zotović 1974:97) exactly like it was the case with the buildings described at the beginning of the $20^{\text {th }}$ century by Miloje Vasić. (Mirković 1968:62) The oldest, first phase of the thermae, dated to the $1^{\text {st }}$ century, was not investigated at the level of its walls, but its existence is presumed according to a hypocaust which was placed under the level of the second phase. The middle phase, from the $3^{\text {rd }}$ century, includes the apsidal walls built in the most frequently used opus incertum mixtum technique, with levelling courses consisting of three brick rows. (Fig. 32) Another technique was also used, called simply opus mixtum, 


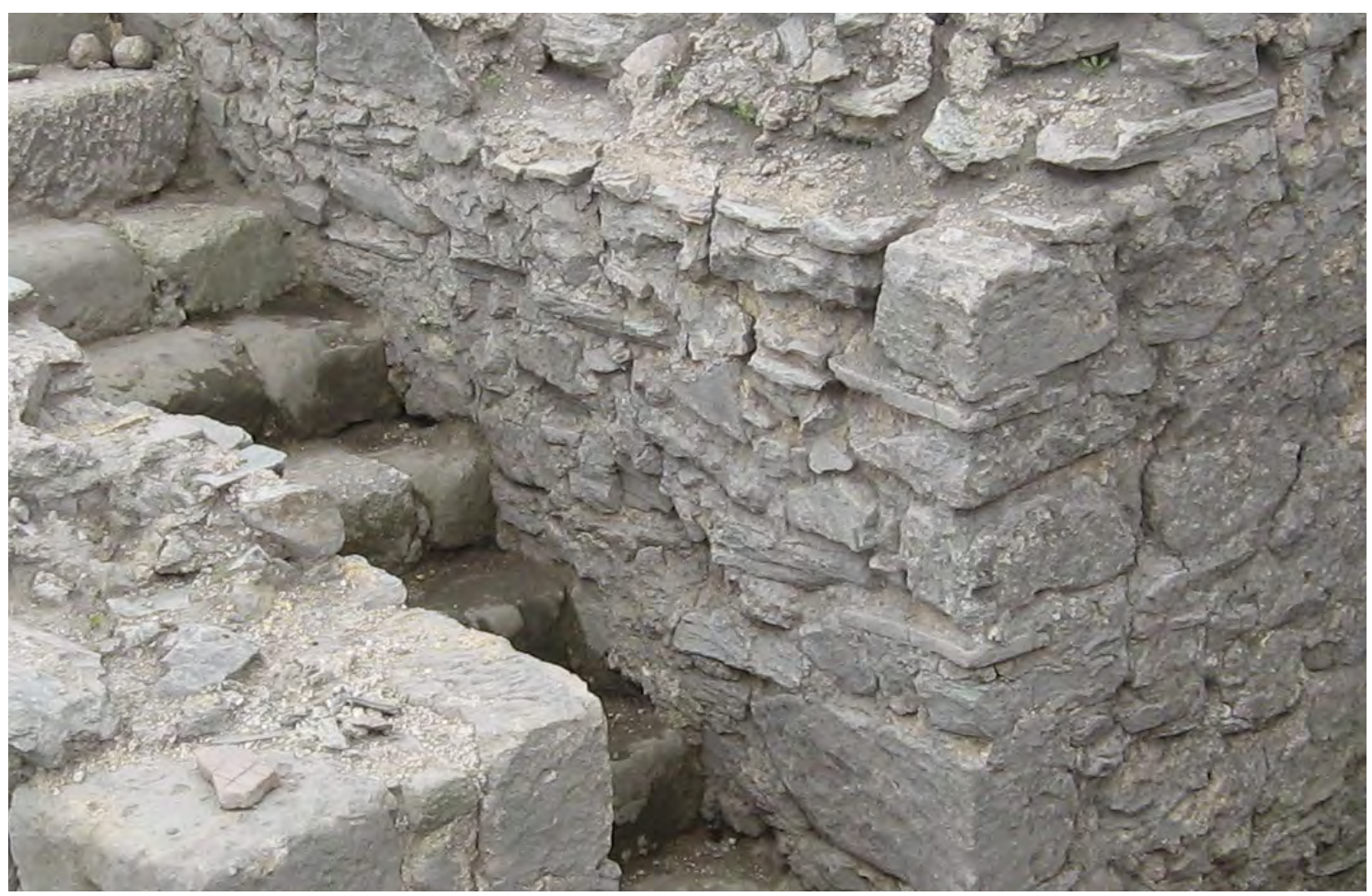

Fig. 25 Opus incertum in the rooms outside the arena of the amphitheatre with visible blocks of limestone on the wall corners. Photo by the author.

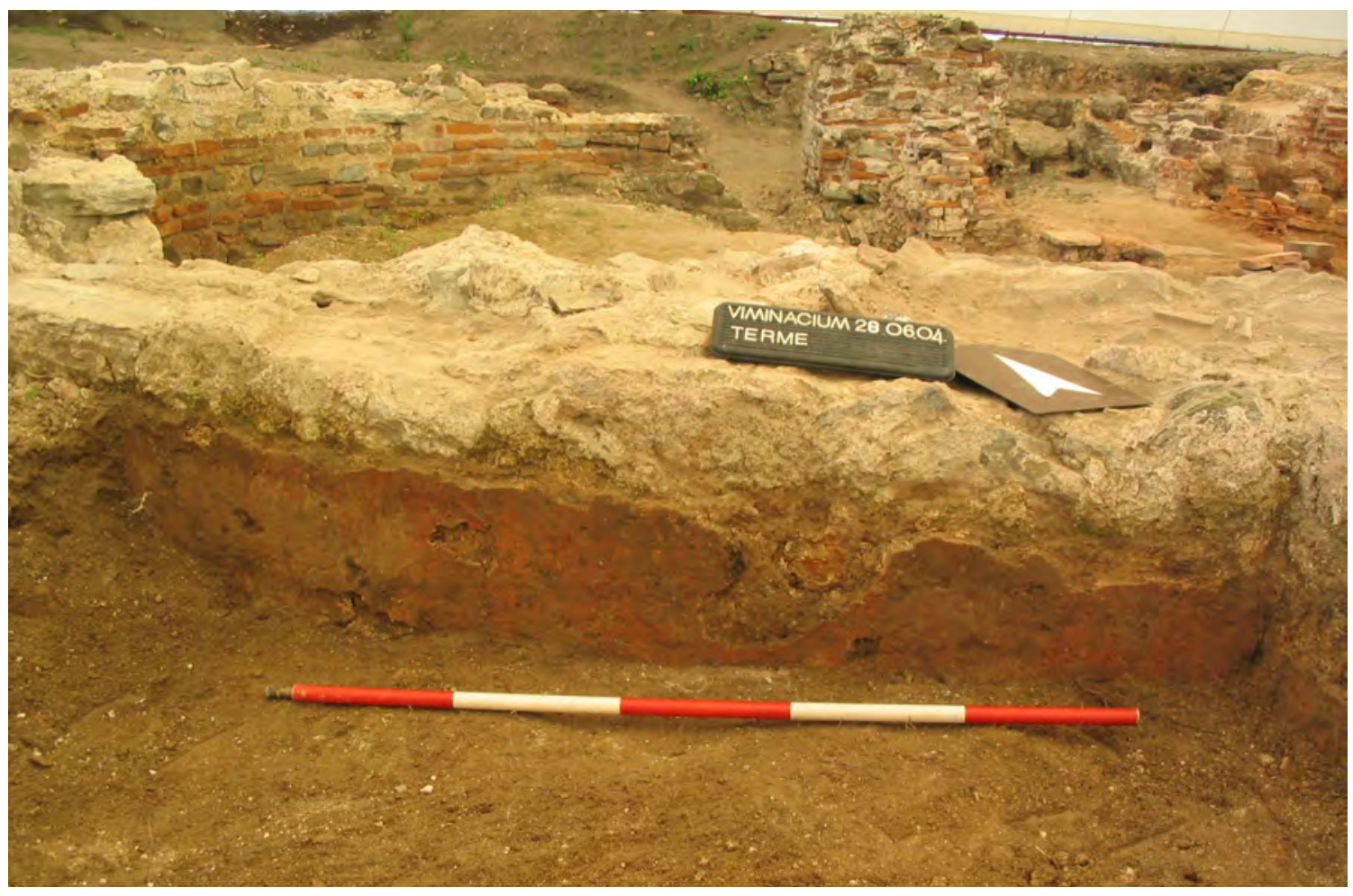

Fig. 26 Plastered wall of an apse in Viminacium thermae. Photo documentation of the Project Viminacium, Archaeological Institute Belgrade. 


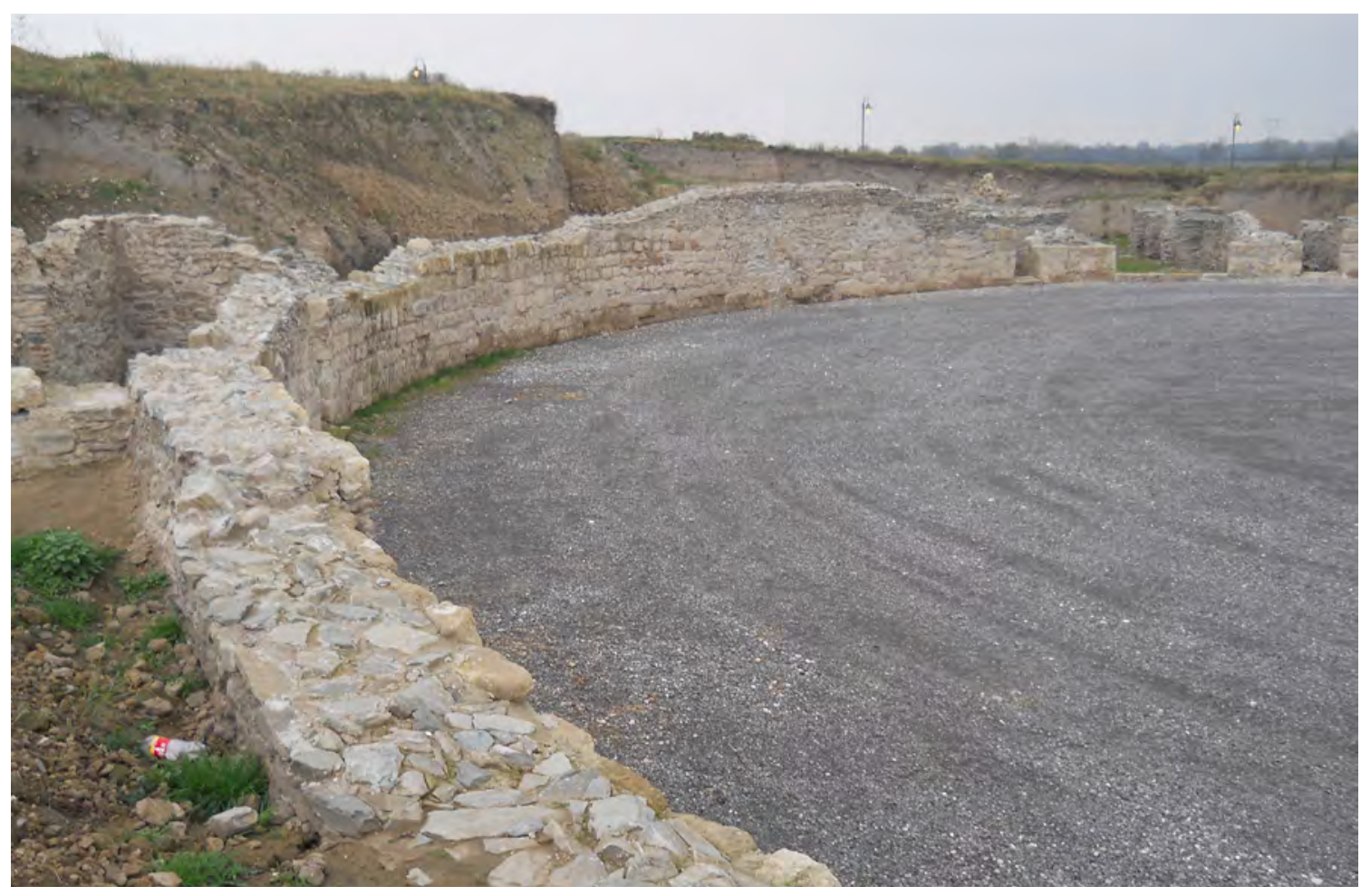

Fig. 27a. Arched wall of the amphitheatre arena. Photo by the author.

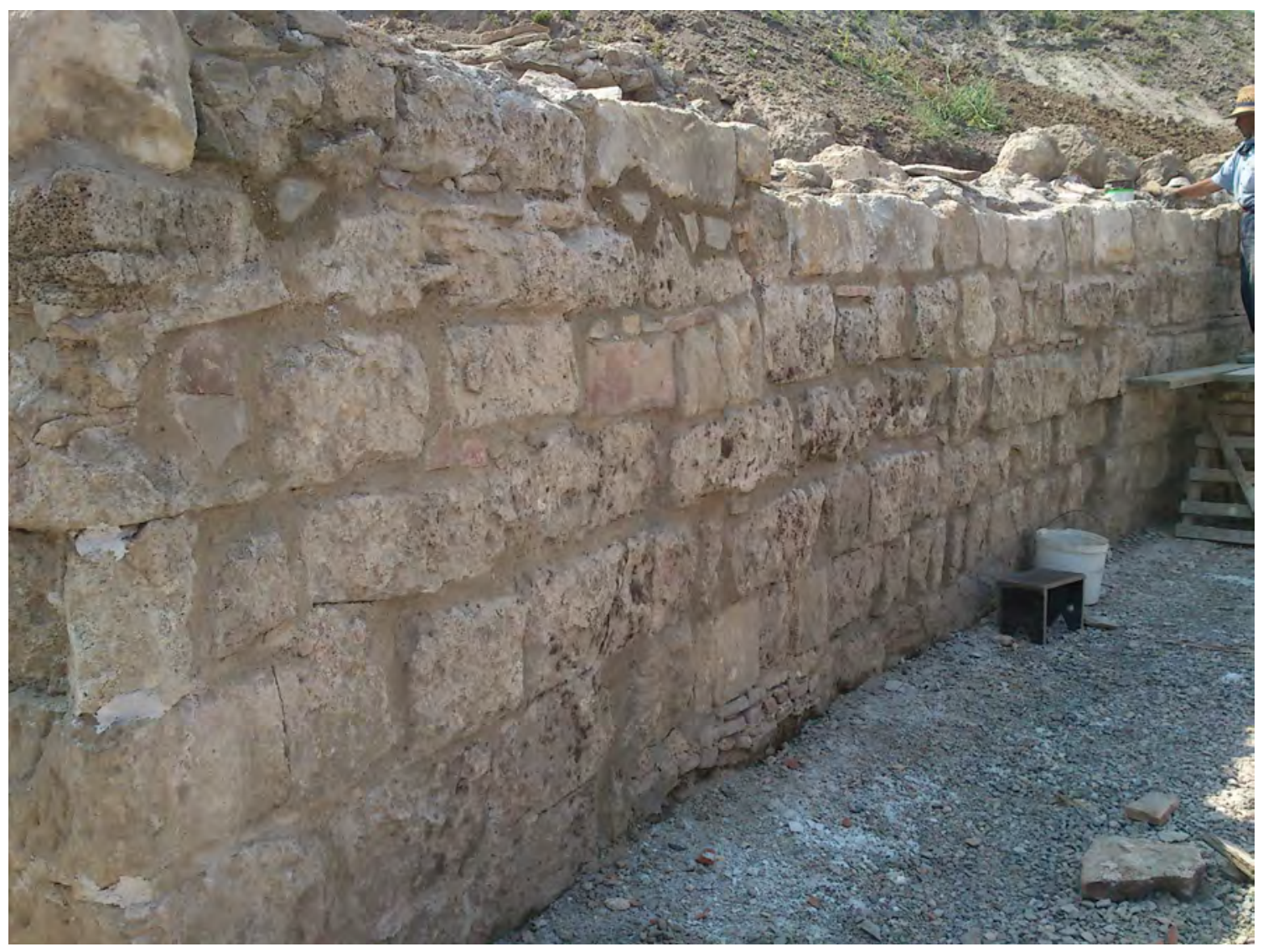

Fig. 27b Arched wall of the amphitheatre arena, detail. Photo by the author. 


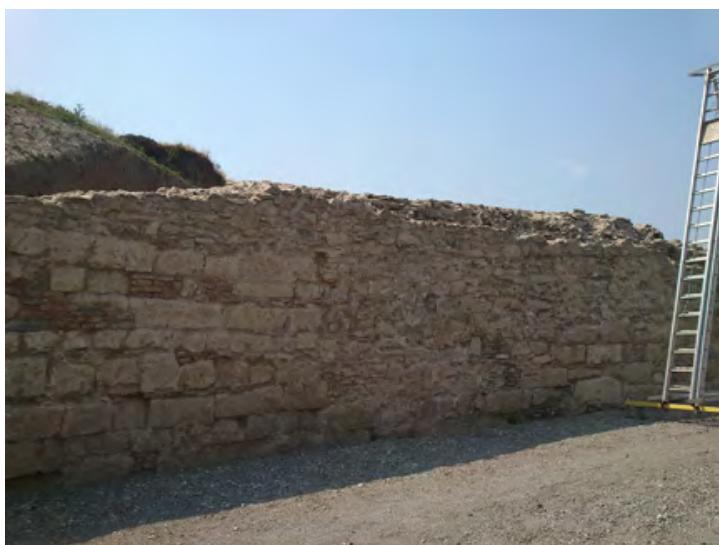

Fig. 28a Arched wall of the amphitheatre arena with visible repairs. Photo by the author.

in which stones and bricks were placed in the wall facing structure in no particular order and with large amounts of mortar. (Fig. 33) However, specific areas with slight groupings of stones and bricks can be noticeable here, along with one or four levelling courses. These can be understood as repairs, i.e. the renewing of a destroyed wall, since this is the only part of the building in which it is visible. The walls

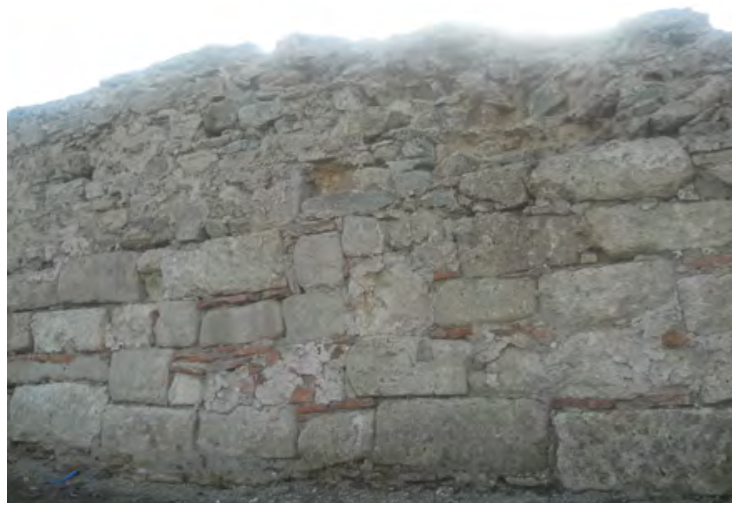

Fig. 28b Arched wall of the amphitheatre arena with visible repairs, details. Photo by the author.

of the youngest third phase, dated to the $4^{\text {th }}$ century, and which was the most damaged one, represent parts of the upper structures. (Fig. 34) The remains are preserved only to a small height and were mostly built of whole bricks and without stones, using the "Byzantine" opus testaceum technique, and, much less frequently, using the opus incertum mixtum technique.

Within the craftsmen's centre, dated to the $2^{\text {nd }}$ and $3^{\text {rd }}$ centuries A.D, (Jordović 1994:103-104) in the pottery kilns area, there is a wall between two kilns preserved up to a height of $3.60 \mathrm{~m}$, (Jordović 1994:103-104), that possesses an interesting structure. It was built of green schist and bricks, with a visible attempt to place schist into regular rows, and use the opus vittatum mixtum technique. Inevitably, due to the irregularities, when this kind of stone is used, it is described as the opus incertum mixtum technique. Partly visible, regular rows of densely placed stones are alternated with a row of bricks with almost invisible mortar joints, which is as a rule repeated six times, after which the building was continued with only schist structures. Another wall of this centre was built using the same technique, and is semi-circular in shape and preserved up to the height of $2.70 \mathrm{~m}$. (Fig. 25)

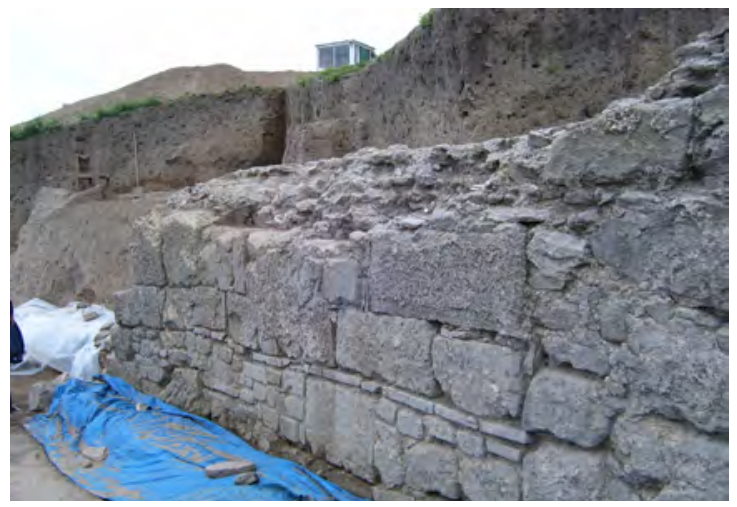

Fig. 29 Arched wall of the amphitheatre with visible bigger and smaller pieces of stone. Photo by the author.

(Jordović 1994:103-104)

It is interesting to mention examples of the opus spicatum technique in the Viminacium buildings, very rarely used for constructing Roman buildings. (Radivojević 2004:56, Adam 1999:288289) The first example is shown in the lowest zone of the surrounding walls of a tomb G-5336 from the site "Pecine", dated into the middle of the $4^{\text {th }}$ century, (Milošević 2006:126-129, app.530) in which a wall was built using this technique, and consists completely of bricks. ${ }^{3}$ (Fig.36) Using the opus spicatum technique, but combining stone and bricks, the foundations of one more building, from the site "Više Burdelja", but with undetermined purpose, were made. They were built on the older necropolis and dated into the second half of the $4^{\text {th }}$ century. ( Jeremić 1978:55-57, plate XXXI, Milošević 2006:147-149, apps. 548-557) For its construction, secondarily used material was also used, such as bricks and tombstones. ${ }^{4}$

3 Ascertained after looking into the photo documentation of the project Viminacium of the Archaeological Institute. 4 Ascertained after looking into the photo documentation of the project Viminacium of the Archaeological Institute 


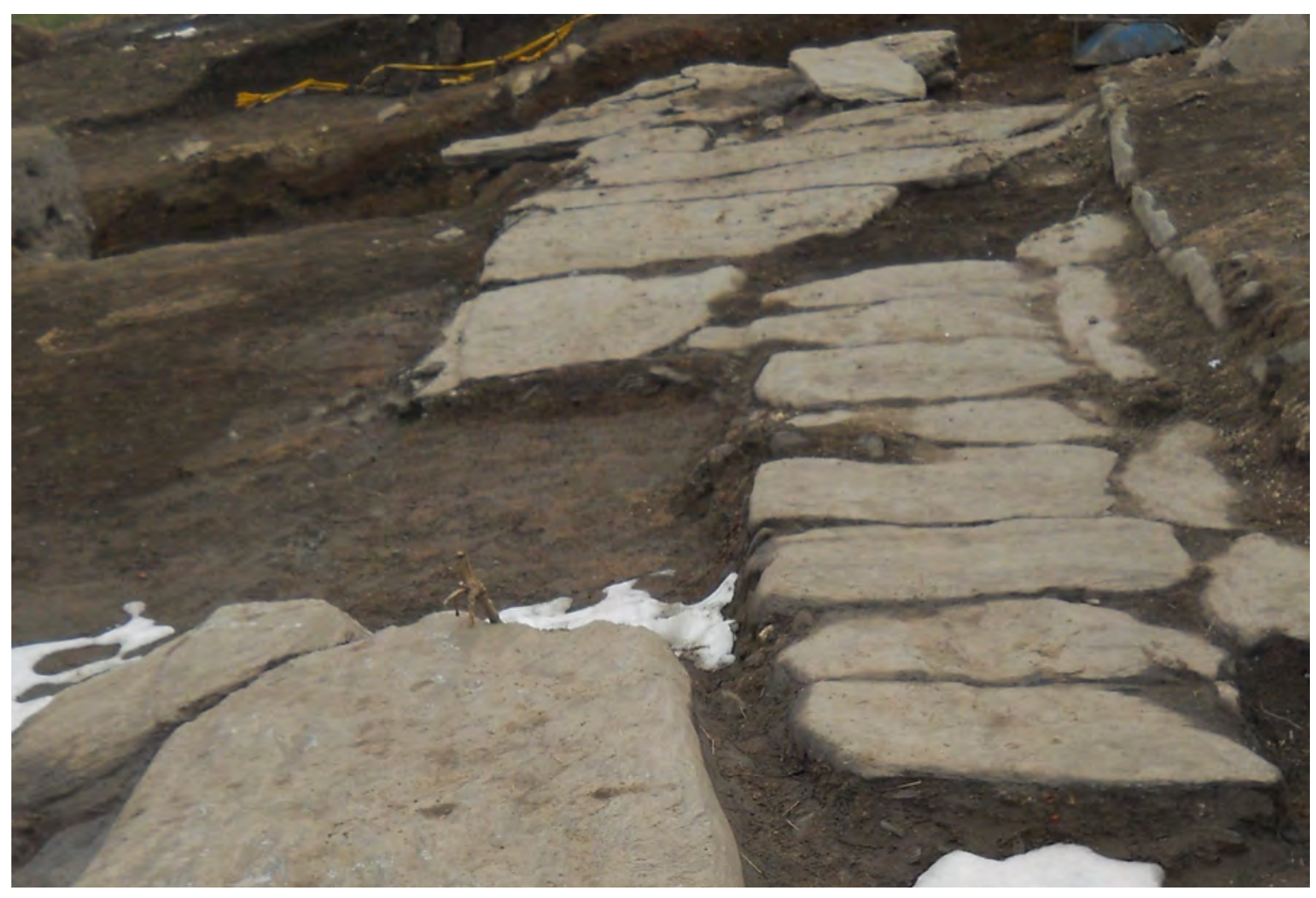

Fig. 30a Street paved with large green schist blocks. Photo by the author.

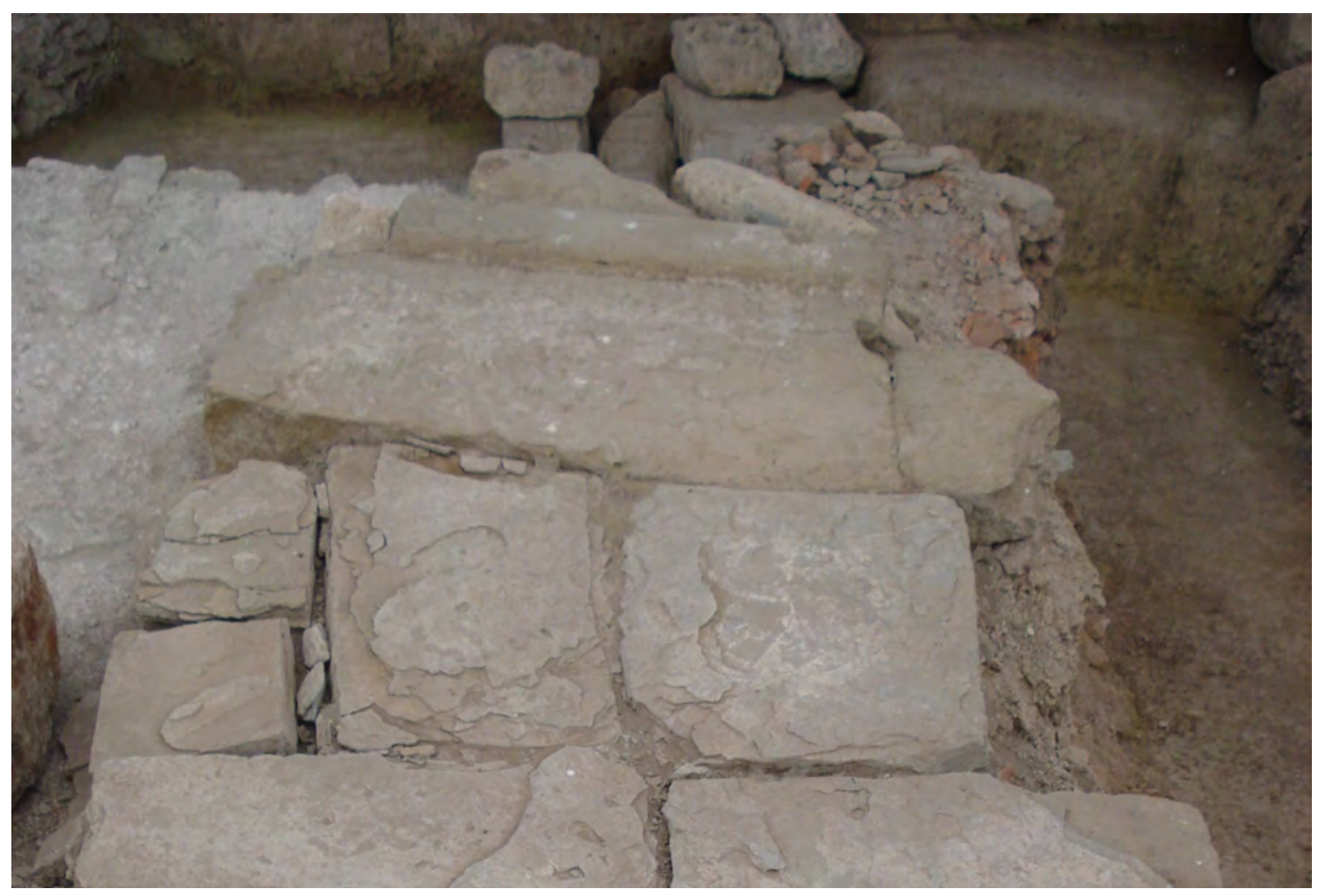

Fig. 30b Street paved with large green schist blocks. Photo by the author. 


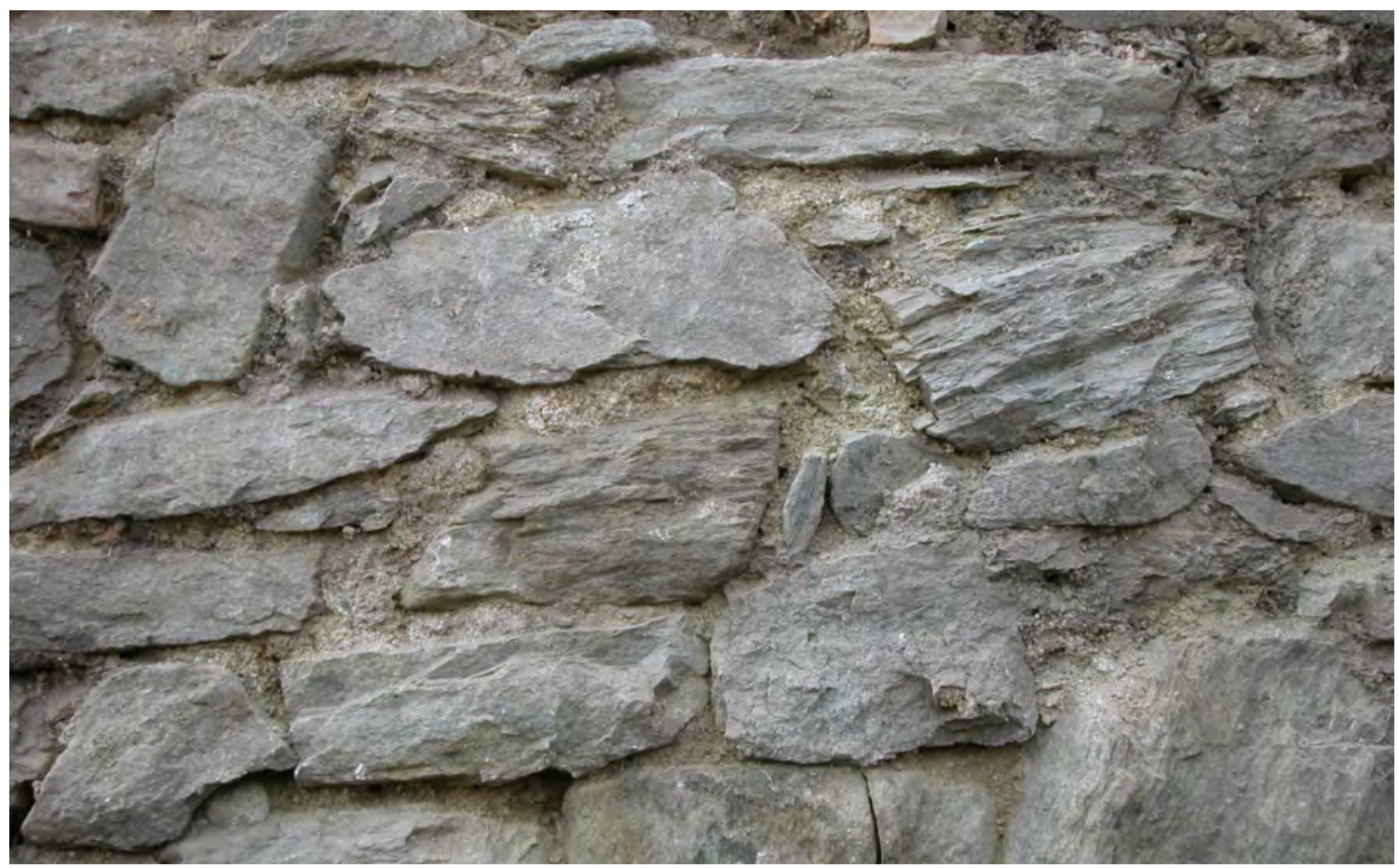

Fig. 31 Opus incertum in the walls of Viminacium thermae. Photo by the author.

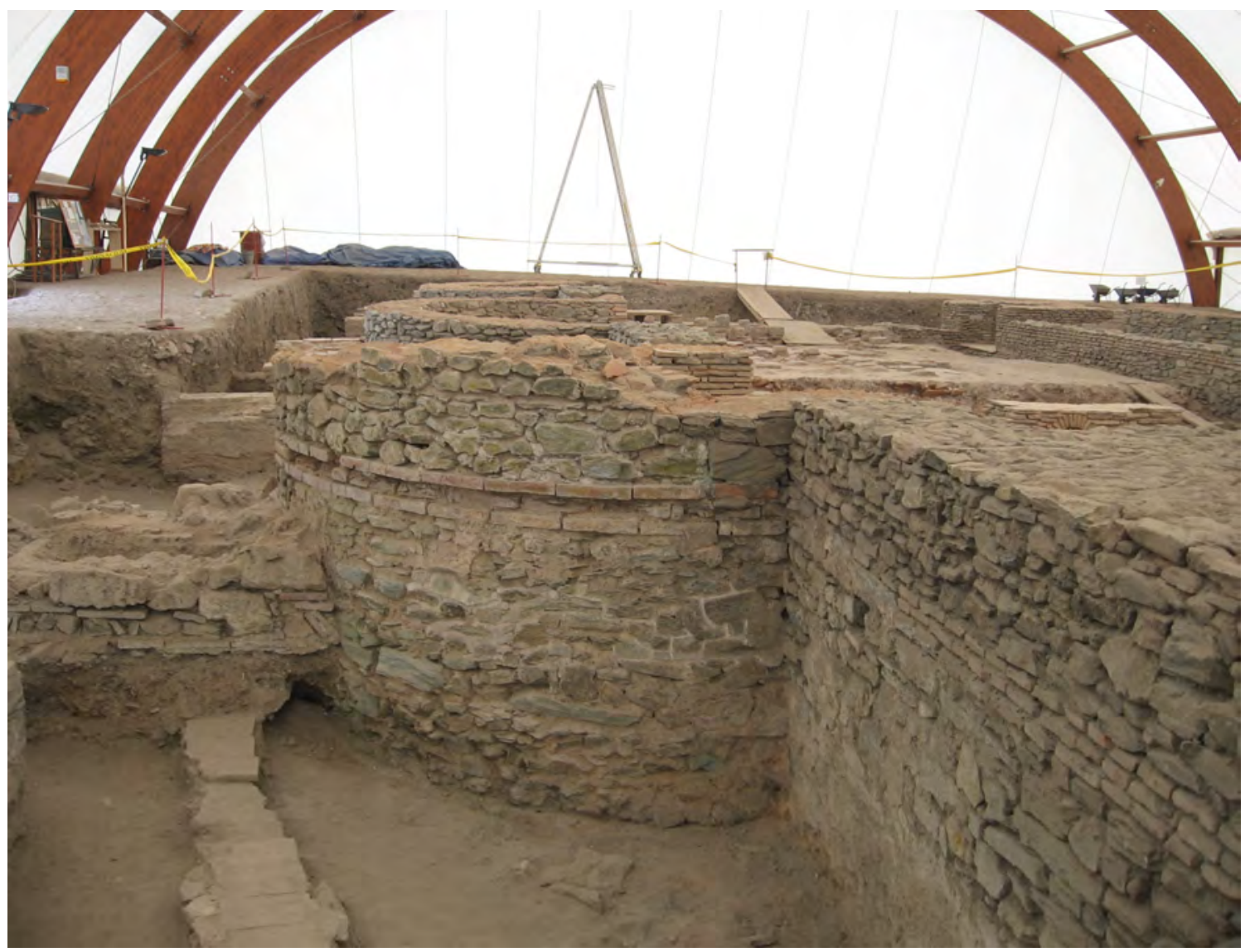

Fig. 32 Opus incertum mixtum in the walls of Viminacium thermae. Photo documentation of the Project Viminacium, Archaeological Institute Belgrade. 


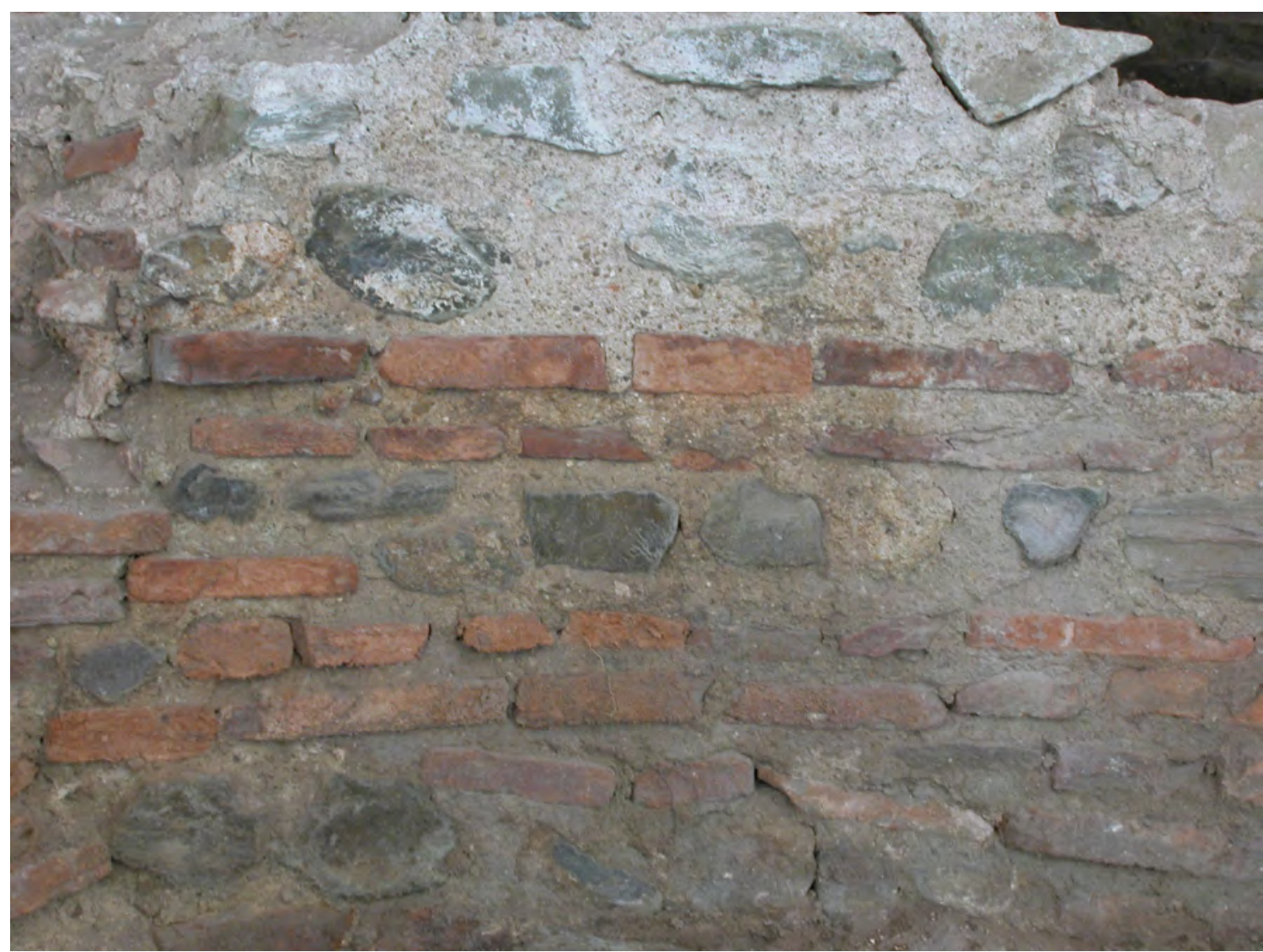

Fig. 33 Opus mixtum in the walls of Viminacium thermae. Photo documentation of the Project Viminacium, Archaeological Institute Belgrade.

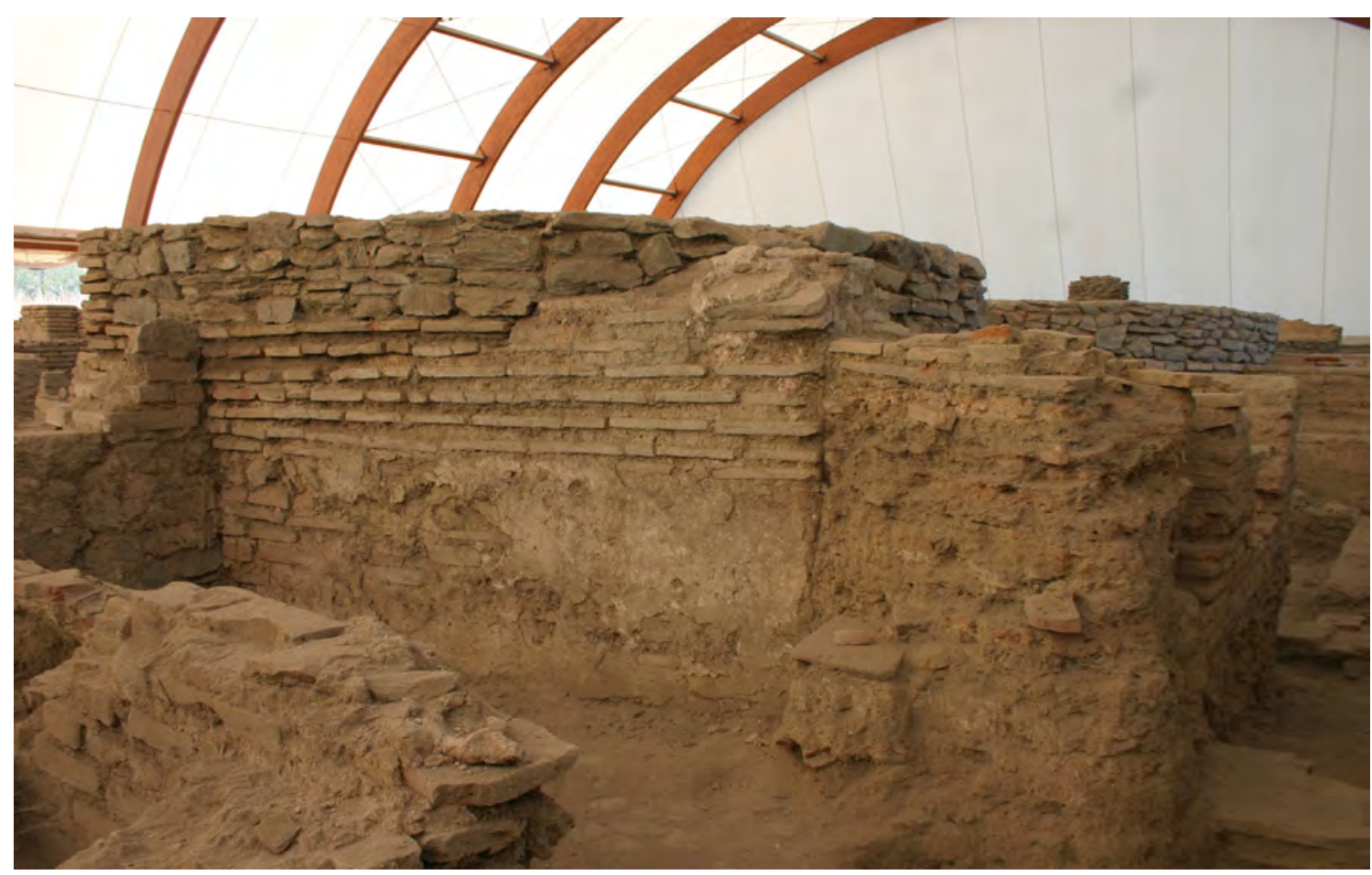

Fig. 34 Opus testaceum in the walls of Viminacium thermae. Photo documentation of the Project Viminacium, Archaeological Institute Belgrade. 


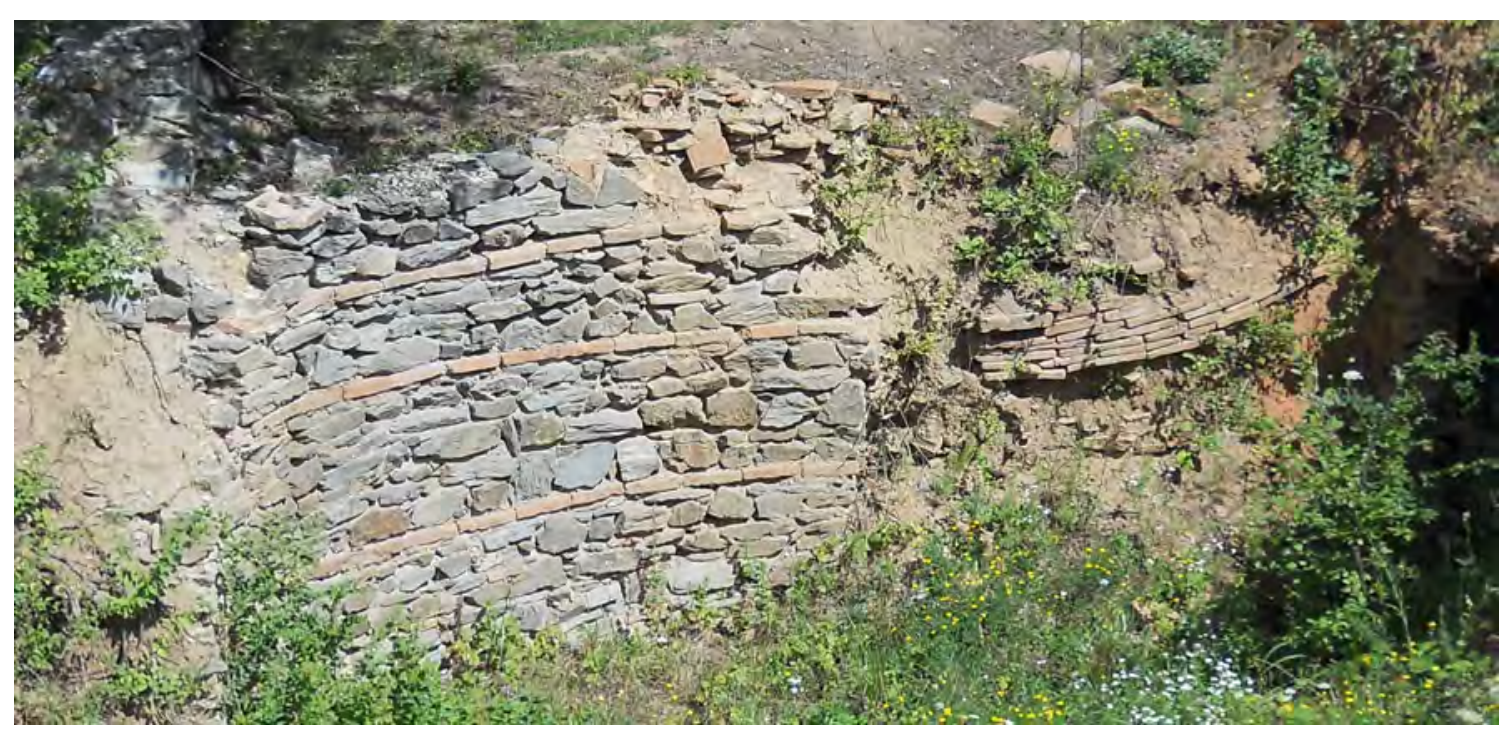

Fig. 35. Opus incertum mixtum done similarly to opus vittatum mixtum in the wall of the craftsmen's centre. Photo by the author.

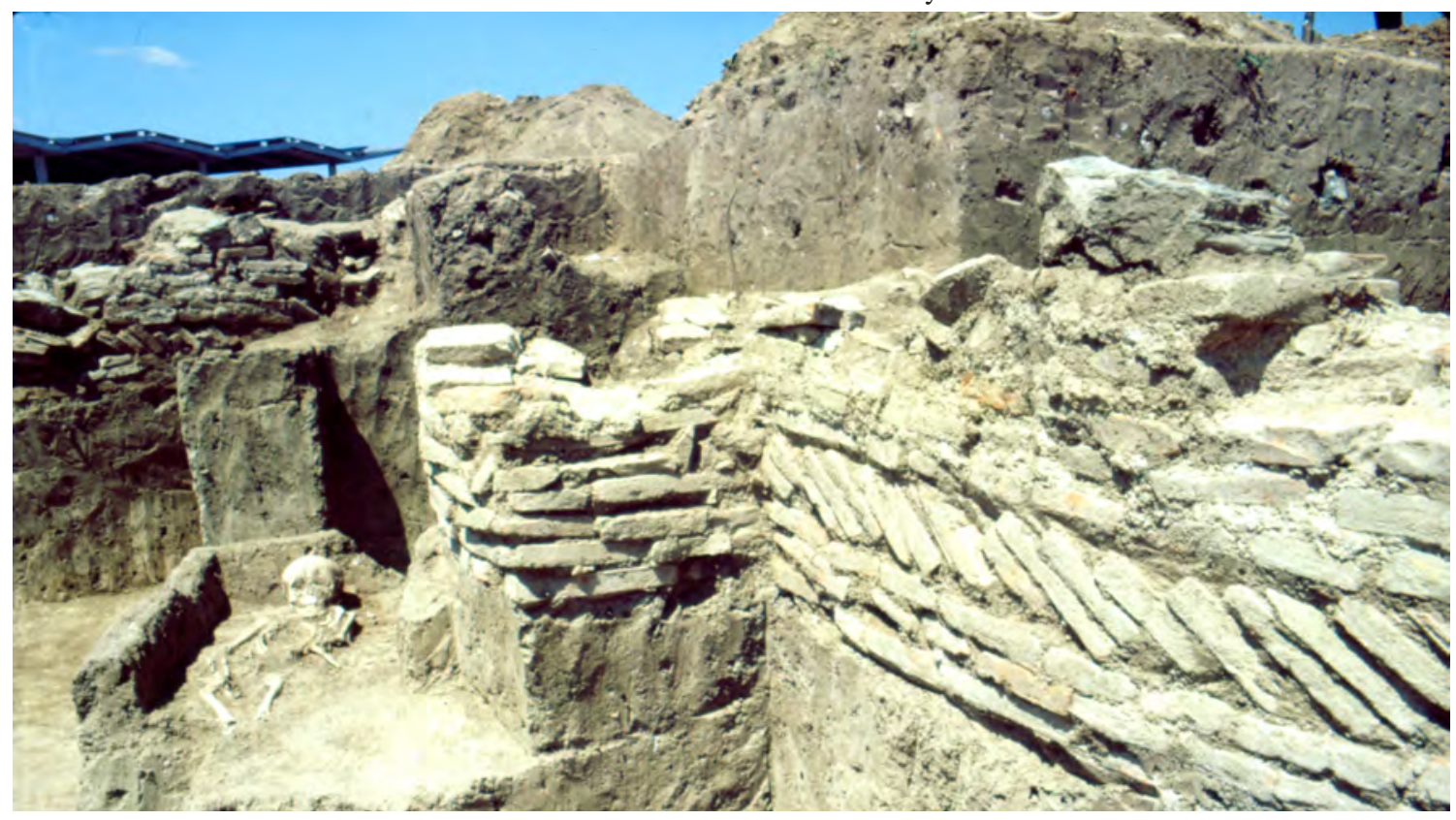

Fig. 36 Opus spicatum in the wall of the tomb.

Photo-documentation of the Republic Institute for the Protection of Monuments.

\section{CONCLUSION}

The use of building materials in a certain age, the methods of their exploitation and production, as well as the techniques of building, can offer valuable data about life in general in an area.

The architecture of Viminacium was, in accordance with general features of ancient Roman architecture, often being forced to be reduced and rationalised in the use of local materials for most of the buildings, but also monumental and luxurious in the use of hard-to-obtain and expensive materials for the most important buildings of this city, the capital of a province on the outskirts of the Roman Empire.

The Viminacium buildings showed that building techniques are in direct connection with building periods of Roman buildings. The techniques followed the basic principles of Roman architecture, but also applied varieties from this part of the eastern Empire, and always respected features of the locally available materials that played an important role throughout the existence of Viminacium, during the ancient, Late Antique and Early Byzantine periods, spanning from the $1^{\text {st }}$ to the $7^{\text {th }}$ century A.D. 


\section{BIBLIOGRAPHY}

Acocella, A. 2006

Stone Architecture. Ancient and modern constructive skills. Trans. Alice Fisher and Patrick John Barr. Milan: Skira-Lucense

Adam, J. P. 1999

Roman Building:Materials And Techniques (1989). Trans. Anthony Matthews. London: Routledge

\section{Andrić, Lj. 2010}

"Proizvodnja nemetaličnih mineralnih sirovina/ Production of Non-metalic Mineral Raw Materials“, u: Mineralnosirovinski kompleks Srbije danas: izazovi i raskršća (Mineral-Resources complex of Serbia today: Challenges and Crossroads). Beograd: Akademija inženjerskih nauka Srbije, Rudarsko-geološki fakultet Univerziteta u Beogradu, Privredna komora Srbije,189-202

\section{Bartel, B., Kondić,V. and Werner, M.R. 1979}

"Excavations at Kraku'lu Yordan, Northeast Serbia: Preliminary Report, 1973-76 Seasons.” Journal of Field Archaeology Vol. 6, No. 2. Boston: Boston University, 127-149

\section{Geokaching}

"Between the villages of Osvetimany and Medlovice lies the only locality with porcelain jasper (porcellanite) in Moravia - Medlovice quarry“, http:// www.geocaching.com/seek/cache_details.aspx?guid=67bdbf9a-e155-43c7-a7e1-10ed837a774e (accessed September, 21st 2012)

Bluemie, J. P., Jacob, A. F., 1973.

Geology along the South Loop Road: Theodore Roosevelt National Memorial Park - North Dacota Geological Survey, Educational Series 4. Medora: Theodore Roosevelt Nature and History Association

Бојовић, Д., 1977

"Римске терме у парку на Студентском тргу у Београду“. Годишњак града Београда XXIV. Београд: Музеј града Београда, 5-22

\section{Цуњак , Мр М.,1995-1996}

"Терме на Орашју - Дубравица код Пожаревца“" Viminacivm 10. Пожаревац: Народни музеј Пожаревац, 105-120
Đurić, B., Davidović, J., Maver, A., Müller, H.W., 2006

"Stone use in Roman towns. Resources, transport, products and clients. Case study Sirmium. First Report“. Старинар 56. Београд: Археолошки институт, 103-137

\section{Golubović, S., 1999}

"A Grave In a Shape of a Well From the Necropolis of Viminacium“. Archaeologia Bulgarica Vol.3. Sofia: Nous Publishers, 9-22

\section{Golubović, S., Korać, M., 2008}

"The Recent Discovery of a Temple Complex at Viminacium“. Roma 2008 - International Congress of Classical Archaeology: Meeting Between Cultures In the Ancient Mediterranean http://151.12.58.75/archeologia/bao_document/poster/5_Golubovic_Korac.pdf (accessed September, 17th 2012).

\section{Gutt, W., Gaze, M. E., 1975}

"Trinidad porcellanite as a pozzolan". Materials and Structures Vol.8, No.6. Dordrecht: Kluwer Academic Publishers, 439-450

Delić Nikolić I., Miličić Lj., Vušović O., Savić, M., Ivović, B. 2011

Izveštaj o ispitivanju uzoraka maltera sa amfiteatra arheološkog nalazišta Viminacijum. Beograd, Institut za ispitivanje materijala a.d.

\section{Jeremić, M.,1978}

"Viminacium - Kostolac: Arhitektura na lokalitetu „Više Burdelja“. Arheološki pregled 19. Beograd: Savez arheoloških društava Jugoslavije, 55-57

Jevtić, D., Zakić D., Harak, S., 2002

"Ispitivanje različitih tipova maltera spravljenih na bazi opekarskog loma“. Materijali i konstrukcije 45. Beograd: Društvo za ispitivanje i istraživanje materijala i konstrukcija Srbije, 60-63

Jordović, Č., 1994

"Grnčarski i ciglarski centar u Viminacijumu“. Saopštenja XXVI. Beograd: Zavod za zaštitu spomenika kulture Srbije, 95-106

\section{Каниц, Ф., 1989}

Србија: Земља и становништво од римског доба до краја XIX века, Прва књига. Београд: Српска књижевна задруга 
Каталог непокретних добара на подручју Града Београда.

"Археолошко налазиште, Утврђење Ad Octavит, Вишњица"

http://151.12.58.75/archeologia/bao_document/ poster/5_Golubovic_Korac.pdf (accessed July 17, 2013).

Kondić, V., Zotović, Lj., 1974

"Viminacium - rezultati arheoloških istraživanja u 1974. godini“., Arheološki pregled 16. Beograd: Savez arheoloških društava Jugoslavije, 94-97

Maravelaki-Kalaitzakia, P., Bakolas, A., Moropoulou, A.,2003.

"Physico-chemical study of Cretan ancient mortars". Cement and Concrete Research 33. Elsevier,, 651-661

\section{Марић, P., 1951}

"Ископавања на Орашју, претходни извештај о радовима у 1945-1949 години““. Старинар II. Београд: Археолошки институт, 113-132

Mašinski fakultet Univerziteta u Beogradu, 2010 TE Kostolac B, postrojenje za odsumporavanje dimnih gasova: Studija o proceni uticaja na životnu sredinu. Beograd: JP Elektroprivreda Srbije

Миловановић, Б., 2008.

"Извештај са систематских археолошких ископавања на локалитету Терме - Виминацијум 2004. године“. Археолошки преглед н.с. 2/3 (2004/5). Београд: Министарство културе Републике Србије и Српско археолошко друштво, 51-54

Милошевић, Г., 2006

Архитектура гробница у римским централнобалканским провнинцијама од IV до VI века. Unpublished PhD thesis, defended at Faculty of Architecture, Belgrade

Милошевић, Г., 1987

"Рановизантијска архитектура на Светињи у Костолцу“. Старинар XXXVIII. Београд: Археолошки институт, 39-63

Mirković, M., 1968

Rimski gradovi na Dunavu u Gornjoj Meziji. Beograd: Arheološko društvo Jugoslavije
Moropoulou, A., Bakolas, A., Bisbikou, K., 2000 "Investigation of the technology of historic mortars”. Journal of Cultural Heritage 1. Elsevier, 45-58

Nikolić, E., Bogdanović, I., 2012

"Proučavanje maltera iz viminacijumskog amfiteatra kao osnova za njegovu buduću konzervaciju i restauraciju”. In: Arheologija u Srbiji: Projekti Arheološkog instituta u 2011. godini. Eds. V.Bikić, S.Golubović, D.Antonović, Beograd: Arheološki institut, 58-61

Nikolić, S., Bogdanović, I., 2012

"Istraživanja viminacijumskog amfiteatra u toku 2011. godine“. In: Arheologija u Srbiji: Projekti Arheološkog instituta u 2011.godini. Eds. V.Bikić, S.Golubović, D.Antonović, Beograd: Arheološki institut, 42-46

Pinheiro, I. S., Montenegro, L.C., and Gumieri, A.G., 2010

"Pozzolanic Activity of Recycled Red Ceramic Bricks". Second International Conference on Sustainable Construction Materials and Technologies 2010, http://www.claisse.info/2010\%20papers/l31. pdf (accessed March 25th, 2012).

\section{Popović, P., 2008}

"Archaeological Finds From the Vaulted Building at Krševica“. Старинар LVIII. Београд: Археолошки институт, 95-106

\section{Поповић, М., 1987}

“Светиња, нови подаци о рановизантијском Виминацијуму“. Старинар XXXVIII. Београд: Археолошки институт, 1-37

Rădan, S.-C., Rădan, S,2012

"Coal palaeofires in the western Dacic Basin: geophysical, mineralogical and geochemical signatures recovered from porcelanites and clinkers; a case history". Second International Conference on Coal Fire Research ICCFR 2012, http://www.coalfire.org/conference/index.php/iccfr2/2010/paper/ view/75 (accessed September 21st, 2012)

\section{Radivojević, A., 2004}

Konstrukcije i tehnike građenja antičkog Rima. Beograd: Orion Art 
Radivojević, A., Kurtović-Folić, N., 2006

"Evolution of Bricks and Brick Masonry in the Early History of Its Use in the Region of Today's Serbia”. J. Mater. Civ. Eng. 18, SPECIAL ISSUE: Innovative Materials and Technologies for Construction and Restoration. Reston, VA: American Society of Civil Engineers, 692-699

Raičković, A., 2012.

Keramičke posude iz grobova tipa Mala Kopašnica Sase. Unpublished PhD thesis, defended at Faculty of Philosophy, Belgrade

Ringbom, Å., Hale, J., Heinemeier, J., Lindroos, A., Brock, F., 2006

"The Use of Mortar Dating in Archaeological Studies of Classical and Medieval Structures". Second International Congress on Construction History 2006, http://www.arct.cam.ac.uk/Downloads/ichs/ vol-3-2613-2634-ringbom.pdf (accessed March 25, 2012).

Томовић, Др М., 1991

"Проконески саркофаг са гирландама из Viminacivma“. Viminacivm 6. Пожаревац: Народни музеј Пожаревац, 69-82

\section{United States. EIS Task Force., 1976}

Alaska natural gas transportation system: final environmental impact statement, Vol.6. The Department : for sale by the Supt. of Docs., U.S. Govt. Print. Off

\section{Валтровић, М., 1884a}

“Откопавања у Костолцу“. Старинар 1, 3. део. Београд: Српско археолошко друштво, 89-104

\section{Валтровић, М., 1884d}

“Откопавања у Костолцу“. Старинар 1, 4. део. Београд: Српско археолошко друштво, 121-142

\section{Васић, М., 1895}

"Колонија Виминацијум: археолошка студија“. Старинар XII. Београд: Српско археолошки друштво, 1-6

Васић, др М., 1907

"Неколике гробне конструкције из Виминацијума“. Старинар н.p.II. Београд: Српско археолошко друштво, 66-98
Вучетић, М., 2010

Из историје српских угљенокопа: Јаме костолачког мајдана. Београд: ЈП „Електропривреда Србије“

\section{Zotović, Lj., 1974}

"Viminacium". Arheološki pregled 15. Beograd: Savez arheoloških društava Jugoslavije, 47-50

\section{Živanović, M , Stamenković, A., 2012}

"O gradskim bedemima antičlke Dokleje/On city Walls of Ancient Doclea”. U/In: Nova Antička Duklja III/New Ancient Doclea II, ur/ed.Dragan Radović. Podgorica: JU Muzeji i galerije Podgorice/ Museums and Galleries of Podgorica, 115-143.

\section{REZIME}

\section{PRILOG PROUČAVANJU RIMSKE ARHITEKTURE VIMINACIJUMA: KONSTRUKTIVNI MATERIJALI I TEHNIKE ZIDANJA}

Ključne reči: Viminacium, zeleni škriljac, opeka, krečnjak, krečni malter, „crvenka”, opus incertum mixtum, opus testaceum, „trpanac“, pucolansko svojstvo.

Najčešće korišćen kamen za izgradnju antičkog Viminacijuma je bio zeleni škriljac, pogodan za temeljne i podzemne konstrukcije građevina. S obzirom da je skoro neizvodljivo obrađivati ovu vrstu kamena u pravilne blokove, zidovi zidani od škriljca su obilato zalivani krečnim malterom. Kao samostalan konstruktivni materijal škriljac nije bio pogodan za zidanje nadzemnih struktura. Zato je najčešća tehnika graditeljstva Viminacijuma bila opus incertum mixtum, koja je uz škriljac podrazumevala i upotrebu opeke.

Odsustvo prirodnih materijala sa pucolanskim svojstvima, neophodnih za nastanak „rimskog betona“, takođe je uticalo na upotrebu određenih tehnika građenja Viminacijuma. Zato je tehnika opus incertum mixtum predstavljala takozvani „vizantijski“ tip, gde je pored opeke, koja je čak i kao sloj za izravnavanje uticala na izgled i ponašanje čitave konstrukcije, veoma 
važnu ulogu nosilo jegro zida, odnosno „trpanac“, kao jedna od glavnih odlika graditeljstva Istočnog Rimskog carstva. Opeka kao lokalni proizvod Viminacijuma formirala je i samostalnu tehniku građenja, „vizantijski“ opus testaceum, koja je $\mathrm{u}$ određenim periodima bila jednako zastupljena kao i već pomenuta opus incertum mixtum. 